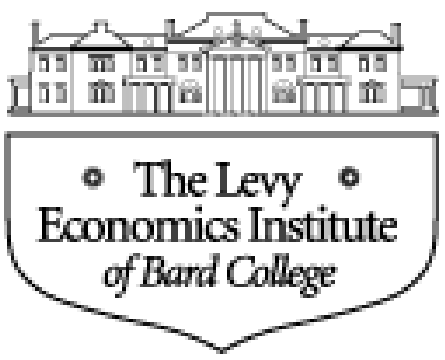

Working Paper No. 479

\title{
European Welfare State Regimes and Their \\ Generosity Toward the Elderly
}

By

\author{
Axel Börsch-Supan \\ Mannheim Research Institute for the Economics of Aging (MEA), University of \\ Mannheim, Germany, and NBER, Cambridge, MA \\ Email Address: axe1@boersch-supan.de
}

November 2006

Paper for the Conference “Government Spending on the Elderly,” The Levy Economics

\section{Institute of Bard College, April 28-29, 2006}

Acknowledgements: I am grateful for the comments by Sergio Nistico, Anette Reil-Held, Christina Wilke and the participants of the Conference on Government Spending on the Elderly at the Levy Economics

Institute at Bard College. Olga Novikova provided very able research assistantship

The Levy Economics Institute Working Paper Collection presents research in progress by

Levy Institute scholars and conference participants. The purpose of the series is to disseminate ideas to and elicit comments from academics and professionals.

The Levy Economics Institute of Bard College, founded in 1986, is a nonprofit, nonpartisan, independently funded research organization devoted to public service. Through scholarship and economic research it generates viable, effective public policy responses to important economic problems that profoundly affect the quality of life in the United States and abroad.

\author{
The Levy Economics Institute \\ P.O. Box 5000 \\ Annandale-on-Hudson, NY 12504-5000 \\ http://www.levy.org
}

Copyright (C) The Levy Economics Institute 2006 All rights reserved. 


\begin{abstract}
This paper examines the generosity of the European welfare state toward the elderly. It shows how various dimensions of the welfare regimes have changed during the past 10 to 15 years and how this evolution is related to the process of economic integration. Dimensions include general generosity toward the elderly and, more specifically, generosity toward early retirement and generosity toward the poor. Using aggregate data (EUROSTAT, OECD) as well as individual data (SHARE, the new Survey of Health, Ageing, and Retirement in Europe), the paper looks at the statistical correlations among those types of system generosity and actual policy outcomes, such as unemployment and poverty rates among the young and the elderly, and the inequality in wealth, income and consumption. While the paper is largely descriptive, it also tries to explain which economic and political forces drive social expenditures for the elderly in the European Union and whether spending for the elderly crowds out spending for the young.
\end{abstract}

JEL Classifications: D1; H55; J26

Keywords: Welfare state, intergenerational redistribution, pension systems 


\section{INTRODUCTION}

Europe is known for its well-developed welfare state, particularly if seen from the American perspective. The GDP share of social expenditures of the EU15 countries in 2001 was 23.9 percent, vis-à-vis 14.7 percent in the United States (OECD Factbook 2006). Some think that the European welfare state is too large because it crowds out economic activities. Indeed, GDP per capita in the United States is almost 50 percent higher than the average of the EU15 countries (see figure 1).

Figure 1: GDP per capita $(E U 25=100)$

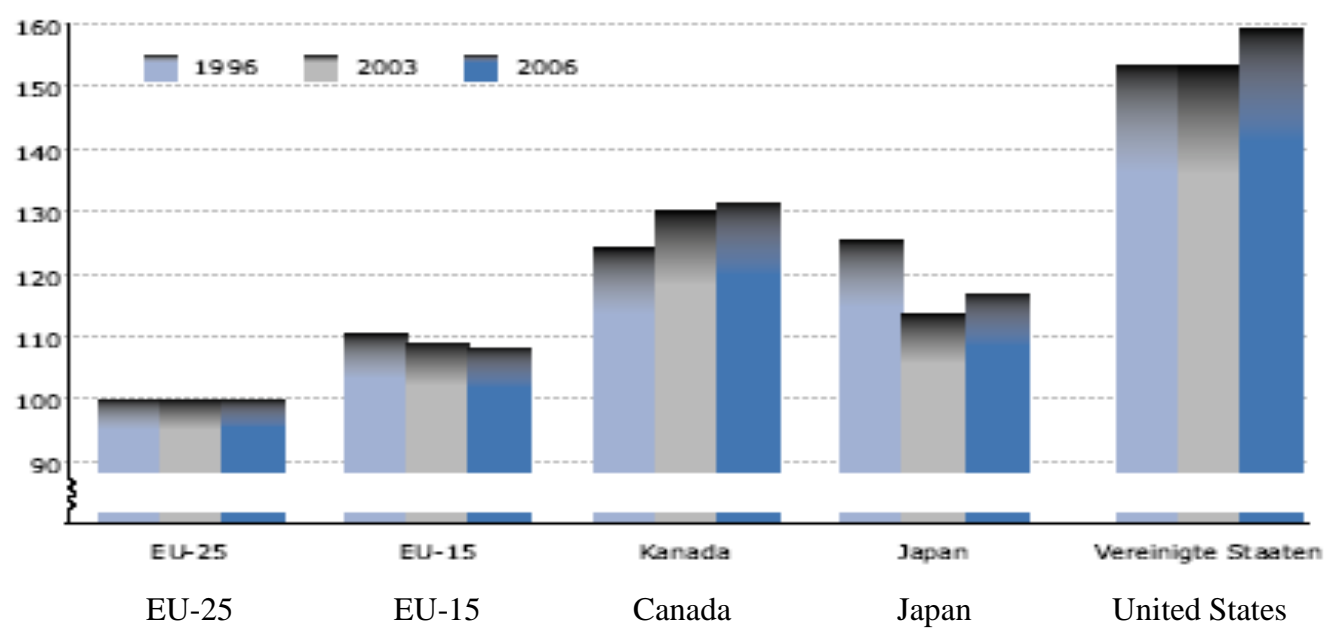

Source: Eurostat Yearbook 2005

Discomfort with this figure, however, is limited in Europe. Europeans cite their longer leisure time, their lower income inequality, and their longer life expectancy (see figure 2).

Figure 2: Income Inequality, Leisure Time, and Life Expectancy at Birth

\begin{tabular}{lccc}
\hline & Annual workhours & Gini & Life Expectancy at birth \\
\hline EU15 & 1,690 & 30.05 & 79.0 \\
US & 1,920 & 35.67 & 77.2 \\
\hline
\end{tabular}

Source: OECD Factbook 2006

This balance may become upset by the demographic aging process. The European population is already much older than the United States population, and population aging con- 
tinues at a faster rate than in the United States due to the lower European fertility rate (figure $3)$.

Figure 3: Population Aging in Europe and the United States: Percentage Age 65 and Older

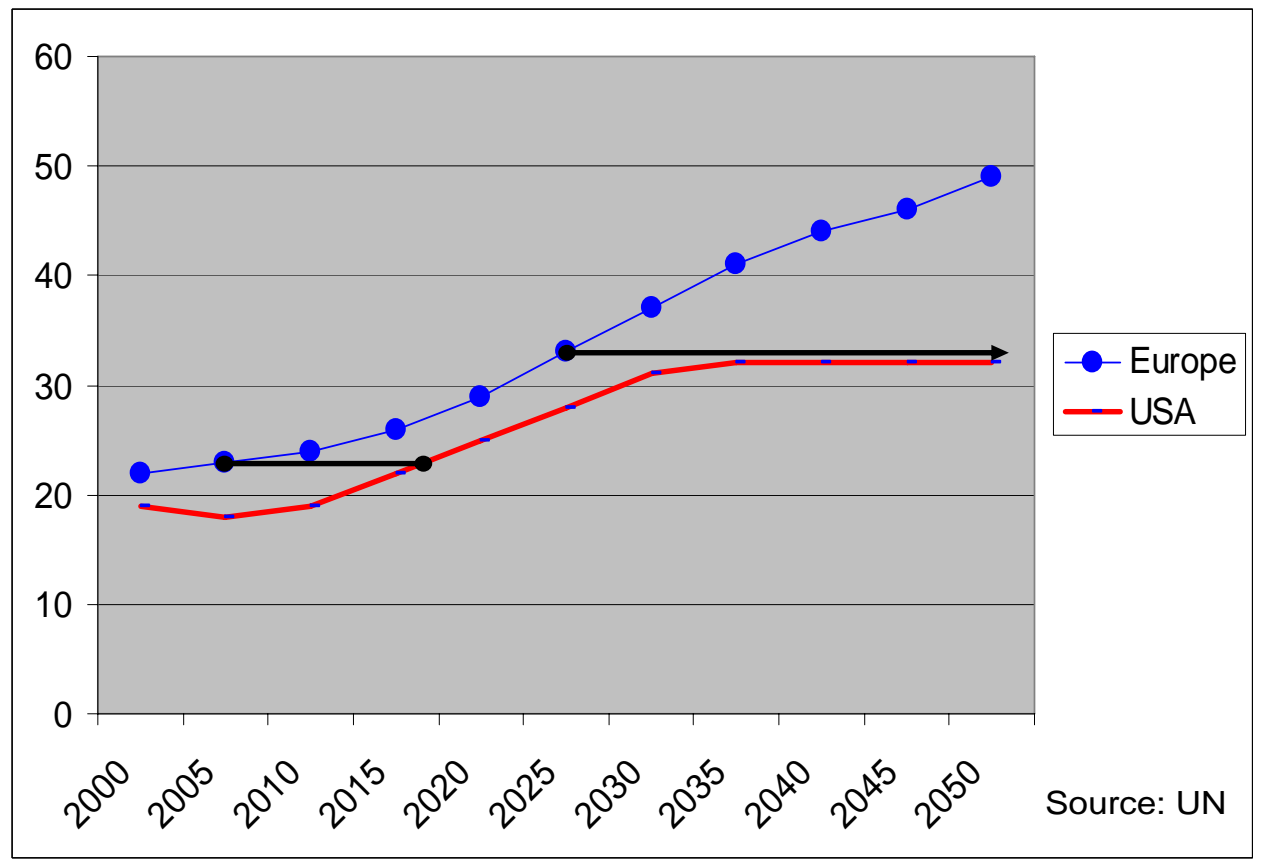

Source: UN population projections, 2002 Revision.

Europe now is as old (measured as share of individuals aged 65 and older) as the United States is projected to be in 2017. Even more dramatic is the aging of Europe past the year 2025. While Europe will continue to age, the proportion of elderly in the United States will stay relatively stable.

Aging implies more social security expenditures toward the elderly (pensions, healthcare, long-term care) per capita, and a forteriori per young and/or employed person. Will the expenditures for the elderly blast the welfare state? Will the welfare state disable itself because the incentive effects created by ever increasing tax and contribution rates will crowd out economic activity, thus eroding the tax base which finances the welfare state? Will spending for the elderly crowd out spending for young families and education, undermining fertility and productivity?

This paper uses aggregate data (official statistics from EUROSTAT and OECD), as well as individual data (from SHARE, the new Survey of Health, Ageing, and Retirement in 
Europe) in order to show the statistical correlations among various dimensions of welfare state generosity. It has a simple structure: System description - Outcomes - Causes. Section 2 describes the European welfare states and their evolution during the European integration process. It compares their generosity to the elderly with the generosity toward the young. Section 3 looks at actual policy outcomes, such as unemployment and poverty rates among the young and the elderly, and the inequality in wealth, income, and consumption. We also look at non-economic outcomes such as health and longevity. Section 4 makes a few steps in the direction of a causal analysis-Why has the generosity of the European welfare state evolved as it did? We offer some demographic and political economy reasons, and collect some evidence on incentive effects. Section 5 concludes.

\section{EUROPEAN WELFARE STATES}

This section describes the European welfare states and their evolution during the European integration process. We first look at the general size of the welfare states, then at their generosity toward the elderly, and finally at expenditures targeted to the young.

\section{2a. General Generosity: Size of the Welfare States}

The size of the welfare state- usually measured as the share of GDP devoted to social expenditures - varies a great deal in Europe, although almost all European countries feature the distinctively higher share than the United States that was mentioned before. The Scandinavian countries, notably Sweden, have the highest social expenditure shares, Ireland the lowest. 


\section{Figure 4: Size of the Welfare State (Social Expenditures per GDP, in Percentages)}

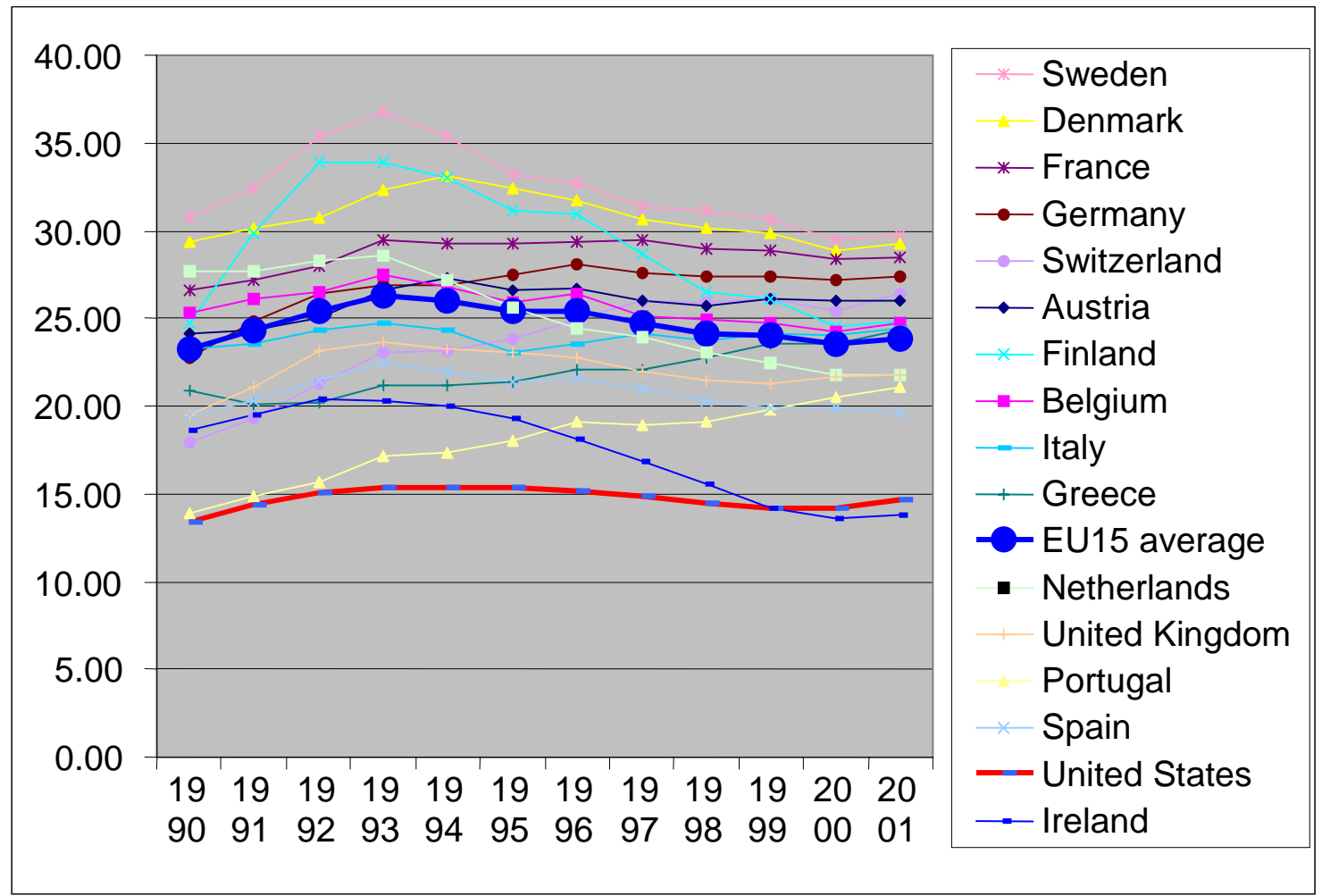

Source: OECD Factbook 2006

The European Union in general, and particularly the Scandinavian countries, experienced a retrenchment of the welfare states in the early 1990s. Quite interesting is the opposite development in Ireland and Portugal, the poorest countries of the EU in the 1980s. While Portugal increased the GDP share of social expenditures throughout the observation period depicted in figure 4, Ireland did not increase social expenditures nearly as fast as their GDP, resulting in the only social expenditure share that is lower than the United States.

Generosity may more appropriately be defined as per capita social spending in purchasing power parity terms. This is depicted in figure 5. According to this measure, Switzerland, Sweden, and Denmark are most generous to their citizens, Ireland and the Mediterranean countries are the least generous welfare states. Of those five countries, however, Italy is much closer to the EU15 average, while the other four countries feature a remarkable gap in per capita social expenditures, vis-à-vis the rest of the pre-accession European Union. 
Figure 5: Size of the Welfare State (Social Expenditures per capita, in Euro PPP)

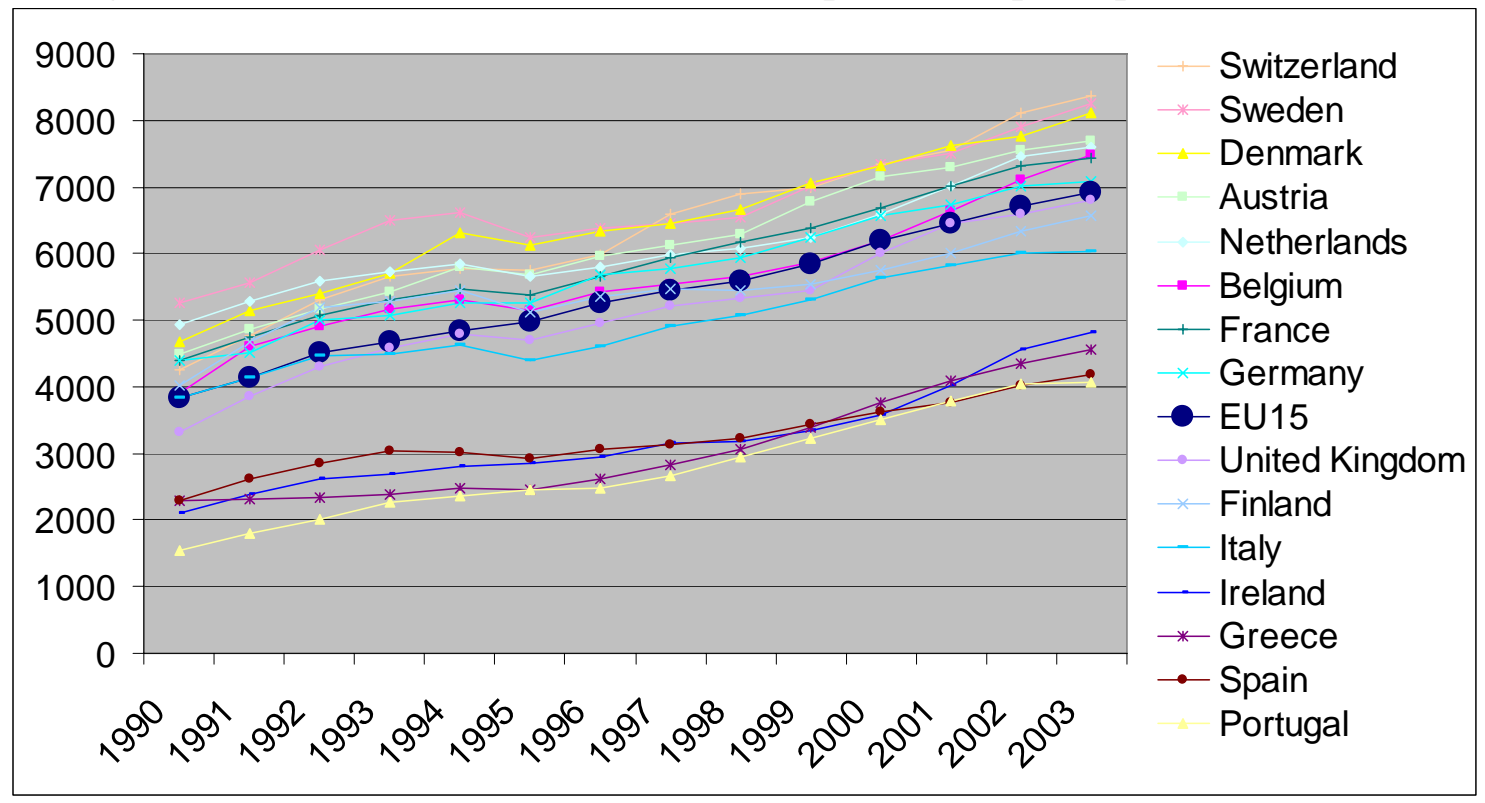

Source: Eurostat Data Archive 2005

Figure 5 also reveals that the growth rates of per capita spending are almost identical for all EU15 countries. While Italy features a particularly low increase and Ireland a particularly large one, these differences are relatively small and there is little sign of convergence. European integration has not—at least no so far-led to an equalization of per capita social expenditures. There is, however, some sign of convergence in the GDP share of social expenditures (see figure 4). Overall, the variety of the European welfare states is large; larger than the three or four archetypical welfare state models, á la Esping-Andersen (2003), suggest.

The following subsection will deepen this point. We will split social expenditures in three parts: spending that can be reasonably targeted to the elderly (mainly pensions, see the following subsection 2b); spending that can be reasonably targeted to the young (mainly education and family allowances, subsection 2c); and spending which may go to the young and the old, as well as the middle aged (e.g., healthcare; this is contained in the figures of this subsection but will not be analyzed separately).

\section{2b. Generosity Toward the Elderly}

Spending for the elderly—here defined as expenditures for old-age, disability, and survivor pensions-is actually diverging in Europe (see figure 6). Sweden and Austria spend the most 
for the elderly on a per capita basis and Ireland spends the least, with a remarkable gap. Portugal, Spain, and Greece have increased their spending on the elderly, but not so much as to converge with the rest of the EU15.

Figure 6: Social Expenditures Dedicated to the Elderly (per capita, in Euro PPP)

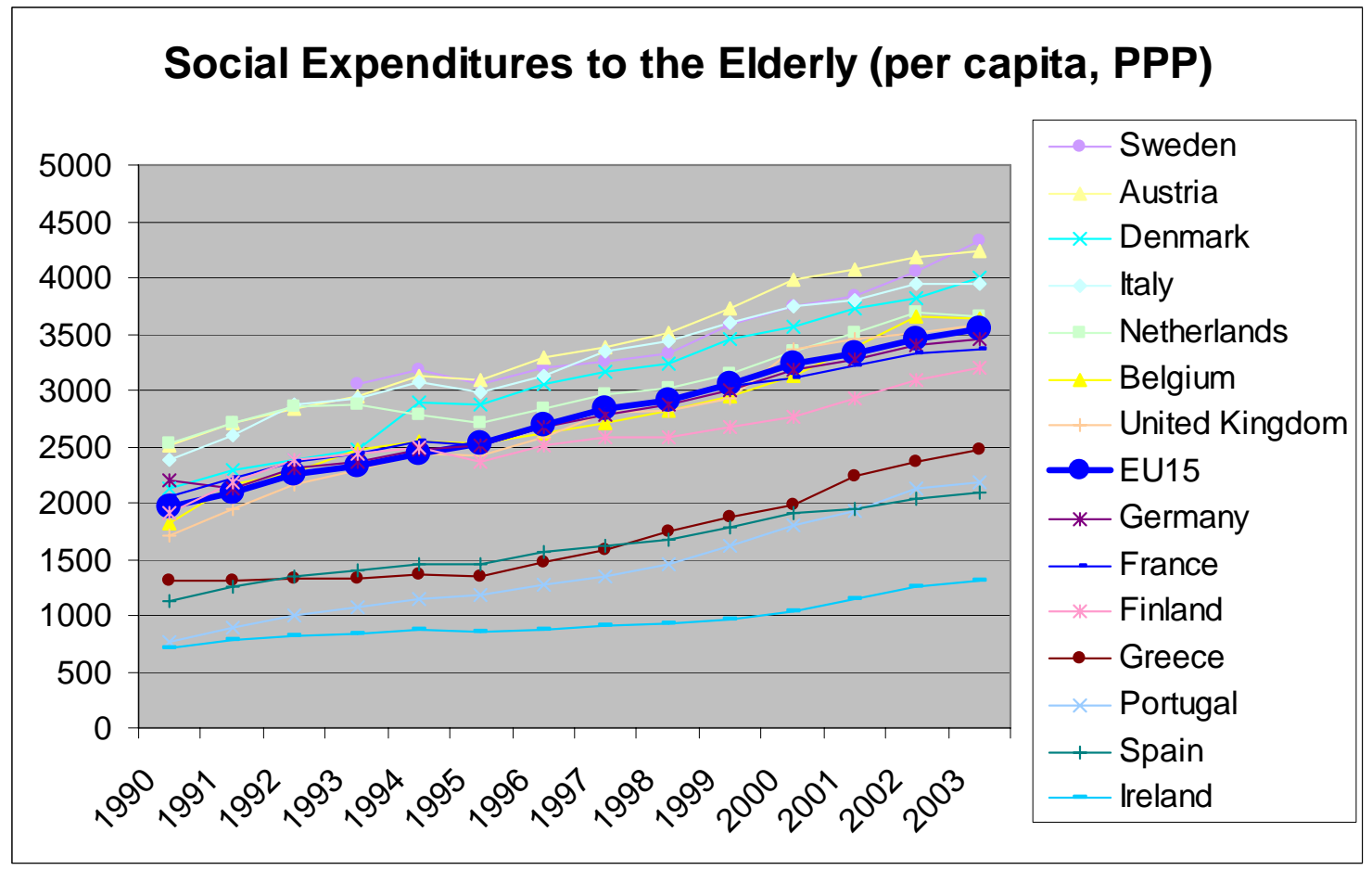

Source: Eurostat Data Archive 2005

Holding total social spending constant, the picture is remarkably different (see figure 7), with Italy and Ireland standing out. Italy spends about 70 percent of the entire social budget on the elderly, 15 percentage points more than the EU15 average, while Ireland spends less than a third of its social budget on the elderly, 25 percentage points less than the EU15 average. Essentially, these expenditure shares have stayed constant over the last 15 years. 
Figure 7: Share of Social Expenditures Dedicated to the Elderly (Percentages of Total)

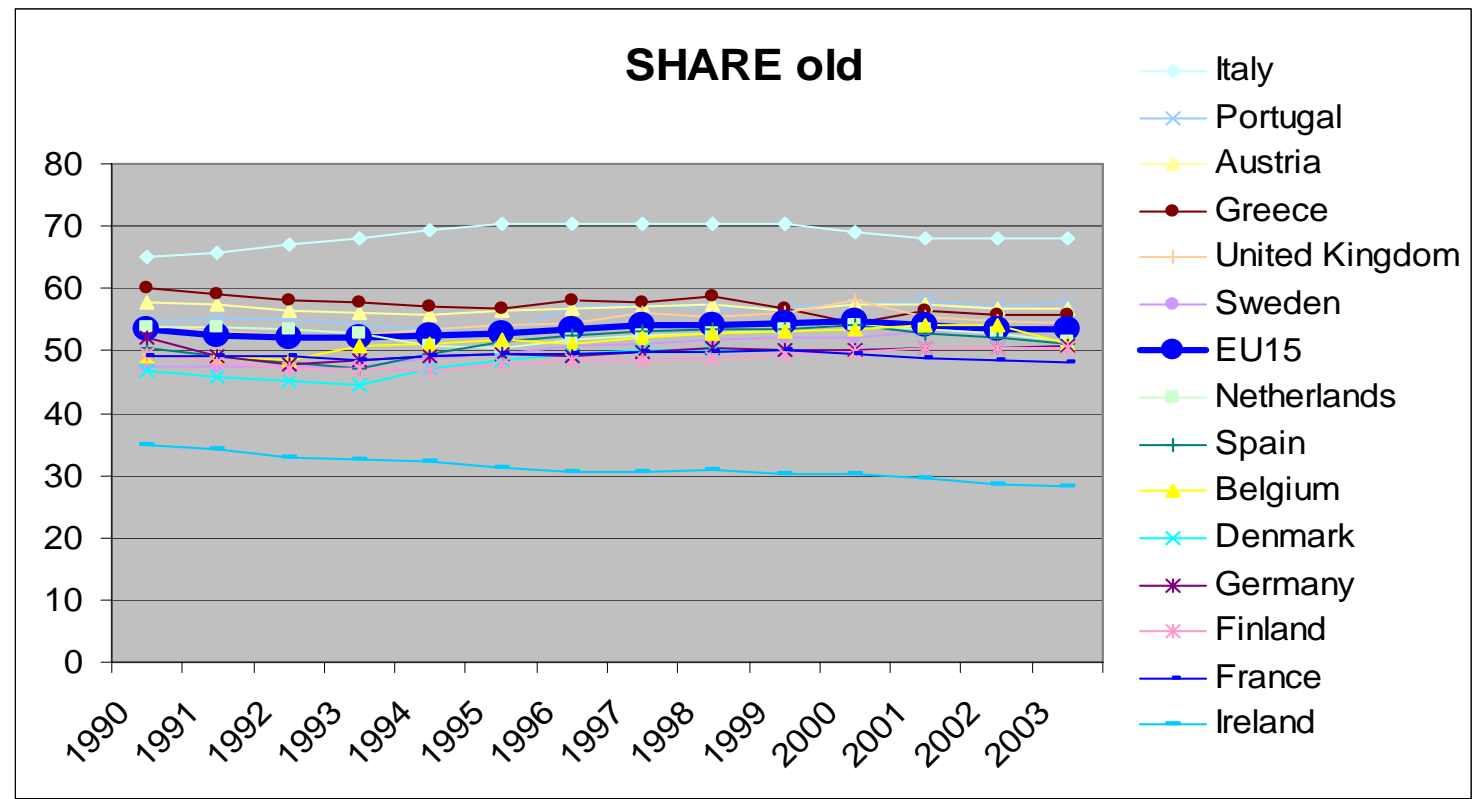

Source: Eurostat Data Archive 2005

\section{2c. Generosity Toward the Young}

Figure 8 corresponds to figure 7 and shows the share of the social budget devoted to the young - defined as family and child support, education, and unemployment benefits. It is not the flip side of figure 7 because healthcare and a variety of smaller social transfers which go to both young and old are not included in figures 7 and 8.

While Italy and Ireland still stand out as extreme, at least in recent years, they do not stand out as extreme with regards to the share of the social budget devoted to the elderly. Remarkable is the great variety of spending shares to the younger generations in Europe-it ranges from about 5 percent to about 30 percent of the social budget. 
Figure 8: Share of Social Expenditures Dedicated to the Young (Percentages of Total)

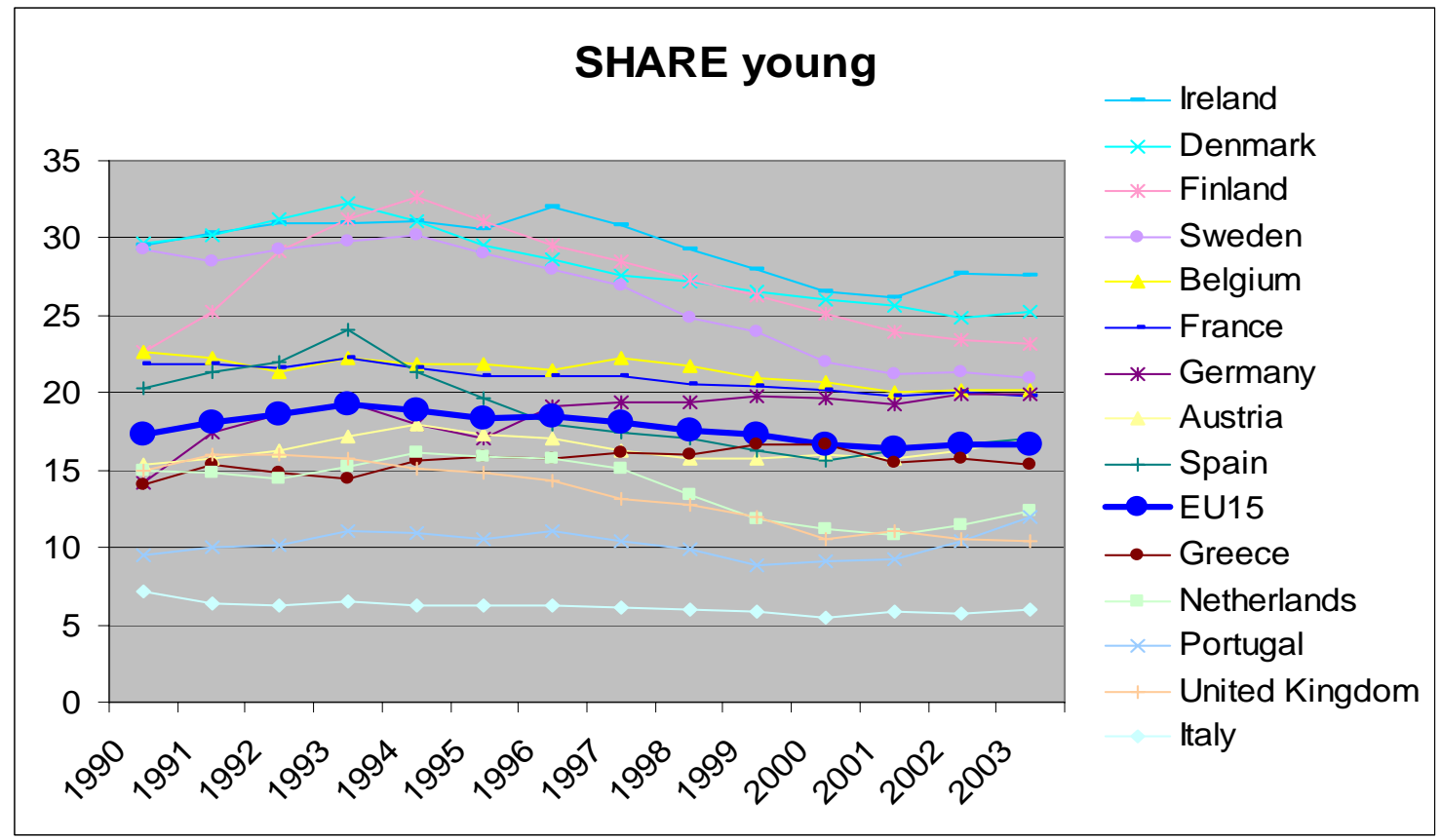

Source: Eurostat Data Archive 2005

Equally different are the per capita expenditures (see figure 9). Here, Denmark and the other Scandinavian countries stand out.

Figure 9: Social Expenditures Dedicated to the Young (per capita, in Euro PPP)

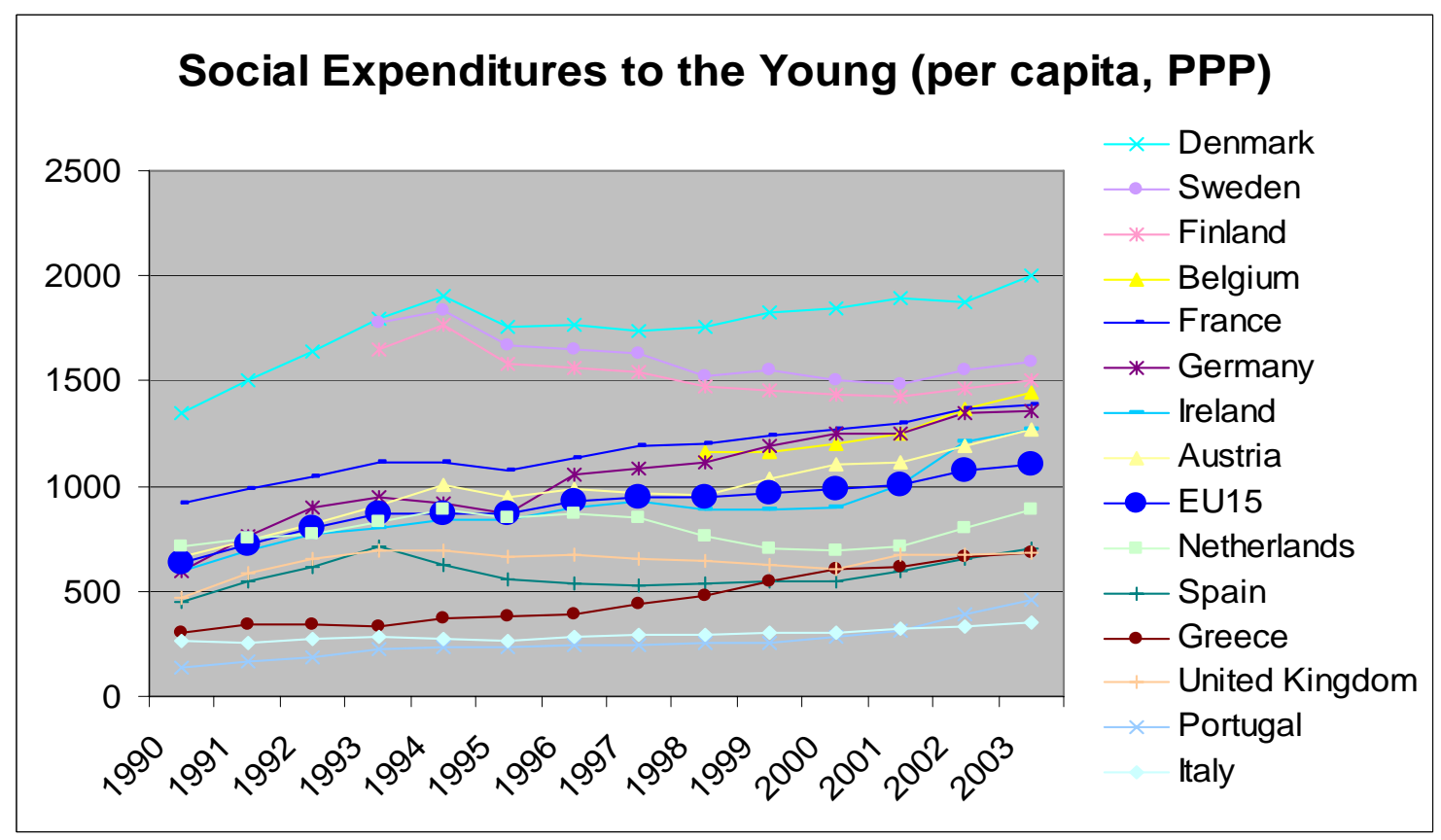

Source: Eurostat Data Archive 2005 


\section{2d. Old vs. Young: Relative Generosity, Crowding Out}

The resulting picture emerges quite clearly (see figure 10). Here, the share of the social budget devoted to the elderly (figure 7) is divided by the share of the social budget devoted to the young (figure 8). For the pre-accession European Union, this ratio is about 3 and has not changed very much between 1990 and 2003. Relative to this benchmark, the Netherlands, Portugal, the United Kingdom, and, by far most pronounced Italy, lean their generosity more toward the elderly, while Ireland, the Scandinavian countries, Belgium, France, and Germany spend a relatively larger share of their social budgets on the young.

Figure 10: Relative Generosity to the Elderly vs. the Young (Social expenditure shares to the elderly divided by social expenditure shares to the young)

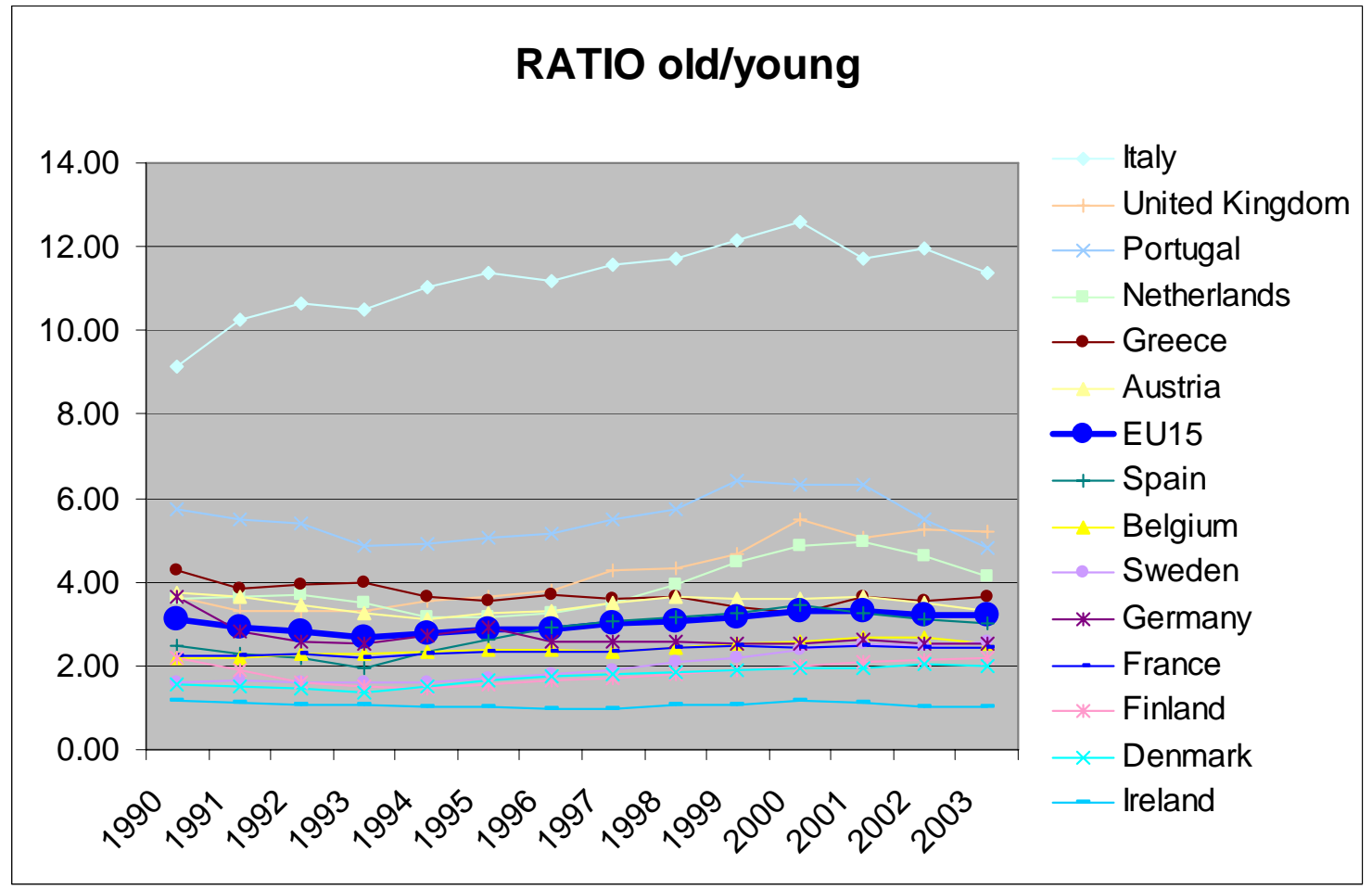

Source: Eurostat Data Archive 2006

The ratio in figure 10 has not changed very much between 1990 and 2003. National spending patterns have stayed rather constant and different from each other throughout this time period, in spite of an accelerated European integration process.

Does this stark cross-sectional variation within Europe teach us something about crowding out? Do we have evidence that spending on the elderly crowds out spending on the 
young? Figure 11 sheds some light on this question. It plots the per capita social expenditures (in Euro at purchasing power parity) depicted in figures 6 and 9 against each other.

Figure 11: Relative Generosity to the Elderly vs. the Young (Expenditure per capita devoted to the elderly versus per capita spending devoted to the young, Euro PPP)

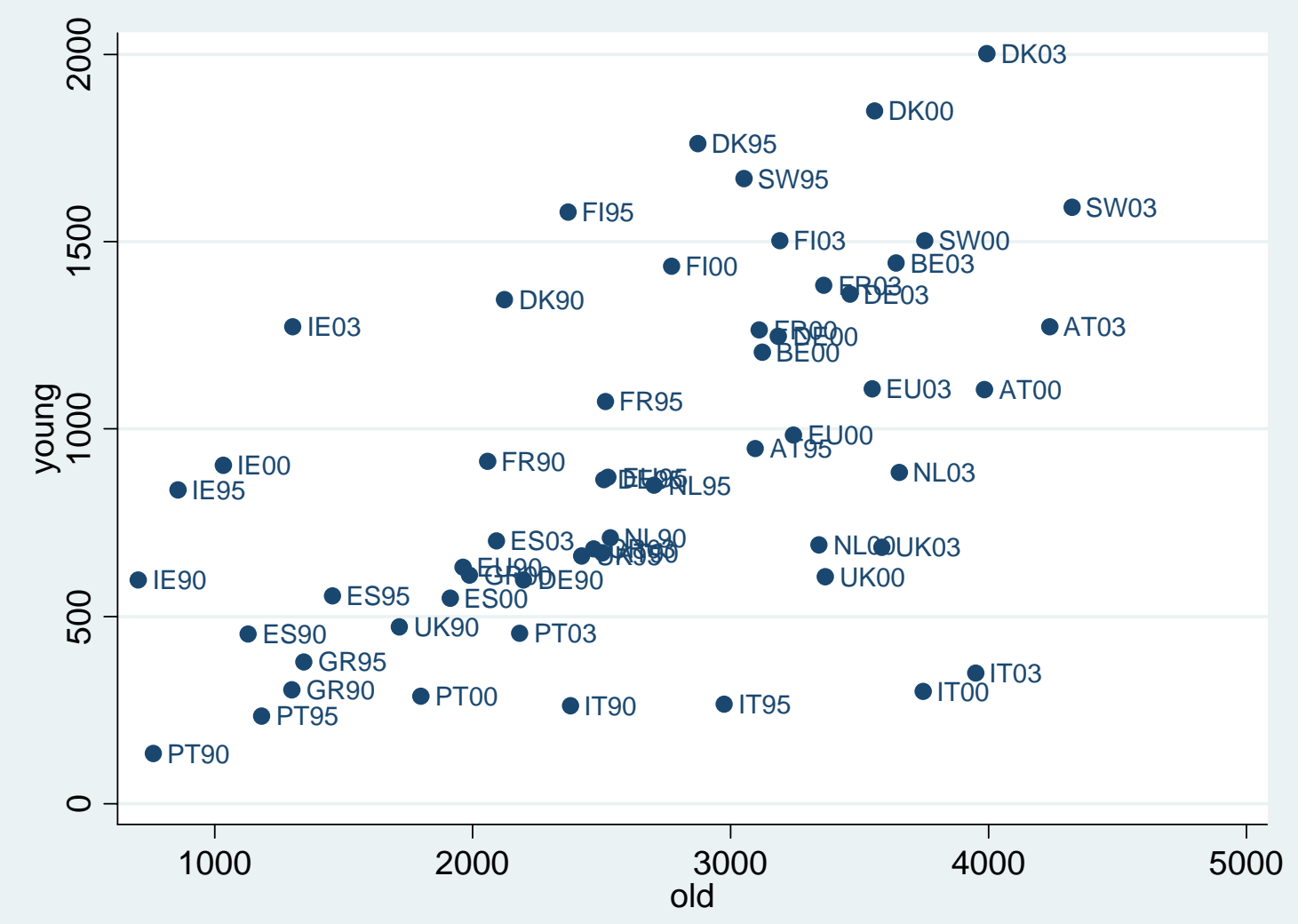

This picture reveals no evidence for a negative correlation between the spending share for the elderly and the spending share for the young. More formally, a pooled regression through the points in figure 11 yields a positively significant coefficient with an $\mathrm{R}^{2}$ of 0.27 . The time series correlation of the EU15 average has about the same slope and an $\mathrm{R}^{2}$ of 0.85 ; and a cross-sectional regression for the 2003 values features a slightly smaller, but still positively significant coefficient with an $\mathrm{R}^{2}$ of 0.12 . The positive correlation can be interpreted as evidence that the welfare states have expanded without much of a trade-off between spending toward the elderly and spending toward the poor. 
Figure 12 repeats this exercise on the basis of spending shares (measured as percentage of GDP). This figure seems to show less of a positive correlation, and, in the case of Italy, maybe even a negative correlation.

Figure 12: Relative Generosity to the Elderly vs. the Young (Social expenditures devoted to the elderly versus social expenditures devoted to the young; percentage of GDP)

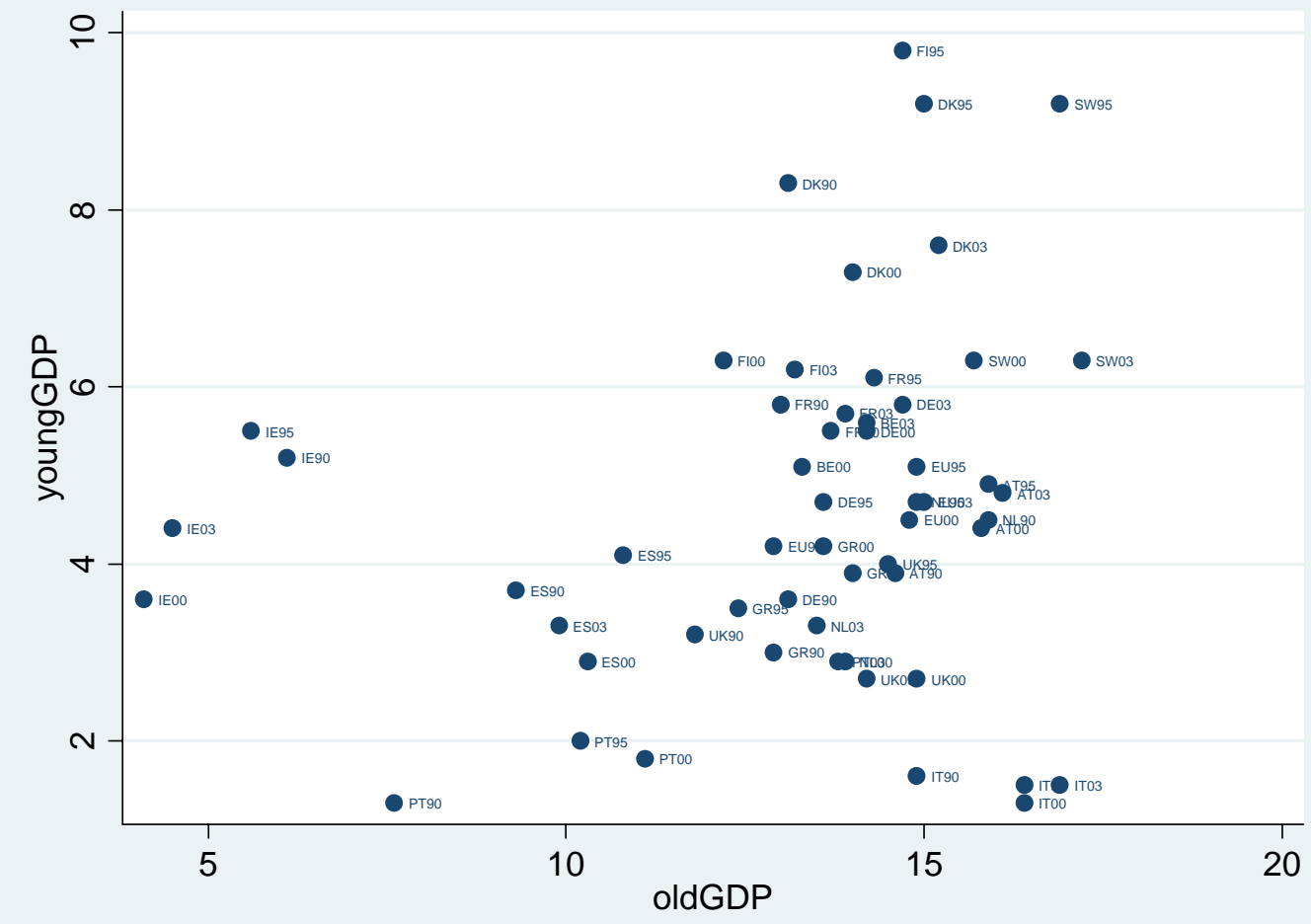

More formally, figure 13 displays a set of time-series regressions by country based on the above data. Indeed, Italy exhibits a negative coefficient, but it is insignificant. In about half of the European countries, the regression produces a significant slope. In all of these cases, the slope is a positive one. The aggregate EU15 regression also features a positive slope, although not significant at conventional levels.

We conclude that there is little evidence for a crowding out effect between being generous to the elderly and being generous to the young. Social spending for the elderly and the young expanded and contracted pretty much in sync with the overall social budget, which increased considerably in absolute terms (figure 5) and consolidated relative to GDP (figure 4). 
Figure 13: Time-series Regressions of Social Expenditure Share Devoted to the Elderly on Social Expenditure Share Devoted to the Young (percentage of GDP)

\begin{tabular}{lcccccc}
\hline Country & Coef. & Std. Err. & t-stat & P>|t] & [95\% Conf. & Interval] \\
\hline EU & 0.97 & 0.60 & 1.6 & $13 \%$ & -0.34 & 2.29 \\
& & & & & & \\
IT & -2.24 & 2.04 & -1.1 & $29 \%$ & -6.68 & 2.19 \\
DK & -0.13 & 0.23 & -0.6 & $57 \%$ & -0.63 & 0.36 \\
UK & -0.02 & 0.39 & -0.1 & $95 \%$ & -0.87 & 0.82 \\
BE & 0.78 & 0.90 & 0.9 & $44 \%$ & -1.72 & 3.27 \\
ES & 0.27 & 0.17 & 1.5 & $15 \%$ & -0.11 & 0.64 \\
FR & 0.78 & 0.44 & 1.8 & $10 \%$ & -0.18 & 1.74 \\
AT & 1.17 & 0.37 & 3.1 & $1 \%$ & 0.36 & 1.99 \\
SW & 0.30 & 0.09 & 3.4 & $1 \%$ & 0.10 & 0.50 \\
DE & 0.96 & 0.24 & 4.0 & $0 \%$ & 0.43 & 1.48 \\
NL & 1.16 & 0.21 & 5.6 & $0 \%$ & 0.71 & 1.61 \\
PT & 3.60 & 0.62 & 5.8 & $0 \%$ & 2.26 & 4.94 \\
GR & 1.89 & 0.32 & 5.9 & $0 \%$ & 1.19 & 2.58 \\
FI & 0.64 & 0.06 & 9.9 & $0 \%$ & 0.49 & 0.79 \\
IE & 0.96 & 0.09 & 10.2 & $0 \%$ & 0.76 & 1.17 \\
\hline SOHE
\end{tabular}

Source: Author's regressions based on the data depicted in figure 12.

\section{POLICY OUTCOMES}

Section 3 looks at actual policy outcomes, such as unemployment and poverty rates among the young and the elderly, and the inequality in wealth, income, and consumption. We also look at non-economic outcomes such as health and longevity. Most of this section is based on the SHARE data, the Survey of Health, Ageing, and Retirement in Europe, collected in 2004.

\section{3a. Income Levels}

Figure 14 examines the actual relative income level of pensioners. It distinguishes young (aged 72 and younger) and old retirees (aged 73 and older) and relates their net public and private income to the total net income of working individuals aged between 50 and 64 . 
Figure 14: Income Level of Retirees (age 72 and less/age 73 and more) Relative to Income of Working Persons Aged 50 to 65
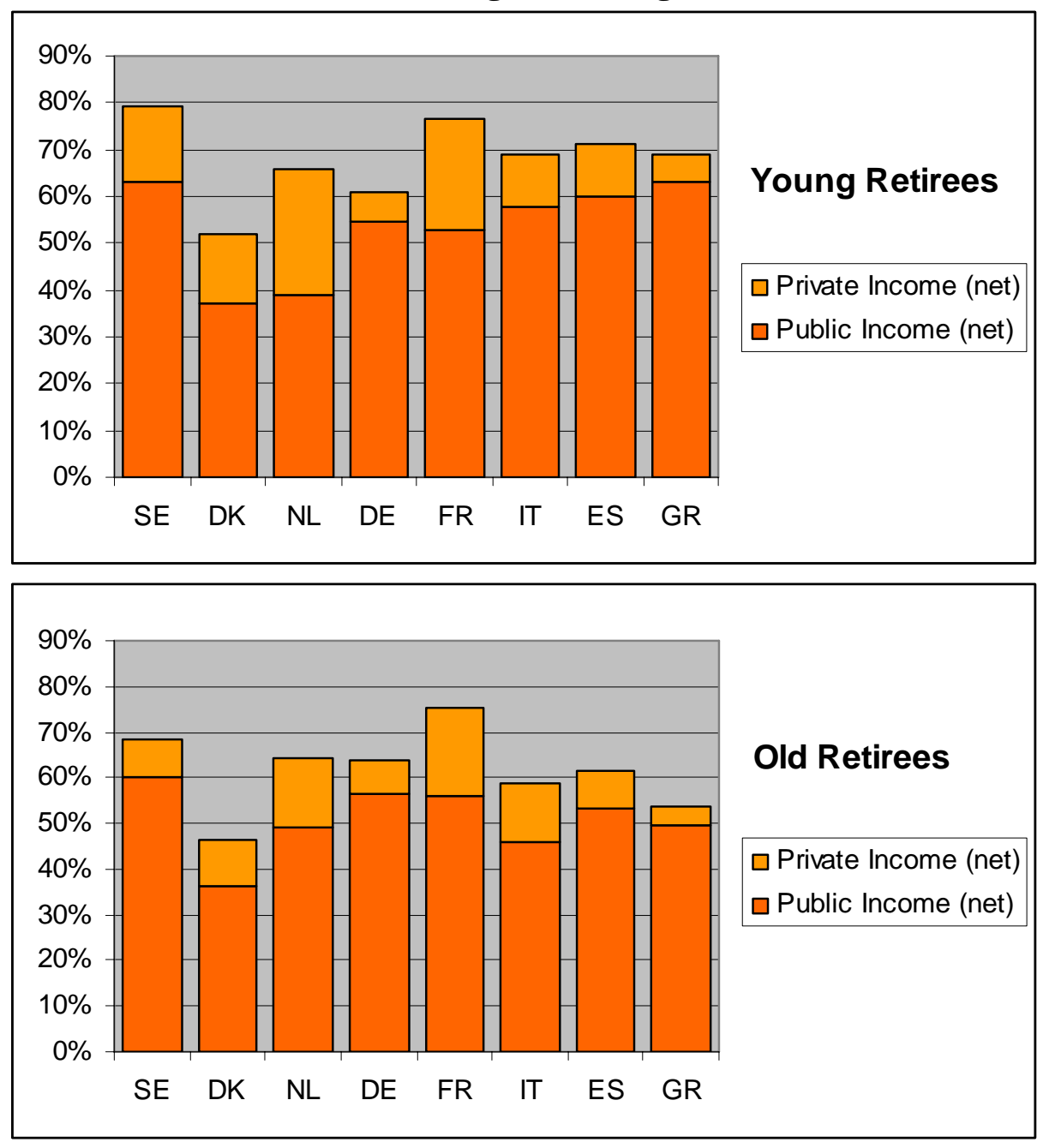

Source: Wilke (2006), based on SHARE 2004

Denmark and the Netherlands have Beveridgian flat-base pensions, while the other countries have Bismarckian earnings-related pensions. For the younger retirees, this is reflected in the much lower relative public income levels in those two countries. In the Netherlands, this is fully compensated by private income (largely occupational pensions), but not in Denmark. The older Dutch retirees still enjoy a much higher pre-reform public pension. In the other countries, old age income is dominated by public pensions.

The patterns in figure 14, based on micro data, are somewhat different from what one might expect after seeing figure 6 , which was based on aggregate spending figures. The case of Denmark catches the eye. If the main goal of welfare state generosity toward the elderly is to prolong accustomed income levels during retirement, then Denmark, which spends consid- 
erably more than the average EU15 country on social expenditures geared toward the elderly, fails.

Another feature that catches the eye in figure 14 is the high income for French retirees. Most additional private incomes are occupational pensions financed pay-as-you-go, while the public pension level, relative to the middle-aged, is in line with the European average.

\section{3b. Distribution of Wealth, Income, and Consumption}

One explanation lies in a different goal of social expenditures in Denmark, namely poverty reduction and income equality. Denmark, together with Sweden, has by far the lowest Gini coefficient on income inequality among the population aged 50+. Note that this is in spite of a considerable wealth inequality in Denmark, pretty much the same as everywhere in the SHARE countries. Consumption inequality, maybe the most appropriate measure for equal living conditions, is also very low.

Figure 15: Distribution of Income, Consumption, and Wealth Among the Elderly (GINI coefficients)

\begin{tabular}{lcccc|}
\hline Macro-Region and Country & $\mathrm{N}$ & Income & Consumption & Wealth \\
\hline Northern Europe & 2,981 & $33 \%$ & $24 \%$ & $60 \%$ \\
SE & 1,787 & $33 \%$ & $22 \%$ & $59 \%$ \\
DK & 1,194 & $32 \%$ & $28 \%$ & $62 \%$ \\
& & & & \\
Central Europe & 6,867 & $46 \%$ & $35 \%$ & $63 \%$ \\
DE & 1,825 & $42 \%$ & $25 \%$ & $62 \%$ \\
NL & 1,741 & $49 \%$ & $46 \%$ & $65 \%$ \\
CH & 743 & $47 \%$ & $38 \%$ & $63 \%$ \\
AT & 1,589 & $51 \%$ & $33 \%$ & $58 \%$ \\
FR & 969 & $47 \%$ & $45 \%$ & $61 \%$ \\
& & & & \\
Southern Europe & 4,021 & $47 \%$ & $41 \%$ & $65 \%$ \\
IT & 1,445 & $41 \%$ & $47 \%$ & $64 \%$ \\
ES & 897 & $56 \%$ & $26 \%$ & $68 \%$ \\
GR & 1,679 & $45 \%$ & $28 \%$ & $52 \%$ \\
\hline
\end{tabular}

Source: Bonsang, Perelman, and van den Bosch (2005), based on SHARE 2004

Income inequality is much larger in the Netherlands. Figure 14 masks the large heterogeneity in additional private income for Dutch elderly. 


\section{3c. Youth and Elderly Unemployment}

France and Denmark are interesting cases because one of the main indicators for successful social policy to the young comes out dramatically different in both countries. While Denmark has one of the lowest youth unemployment rates of the OECD countries, France has by far the highest youth unemployment rate in Europe, topped in the OECD only by Turkey and the Slovak Republic. French social spending levels on the young are above EU15 average (see figures 8 and 9), however, much of this goes to family and child subsidies, while less goes to education than in other European countries. In a very broad sense, one might interpret this finding as a kind of crowding out, with public attention focussed on maintaining the income level of retirees crowding out attention to the unemployment situation of the young.

Figure 16: Percentage of Youths Aged between 15 and 19 Who Are Not in Education, nor in Employment, 2003

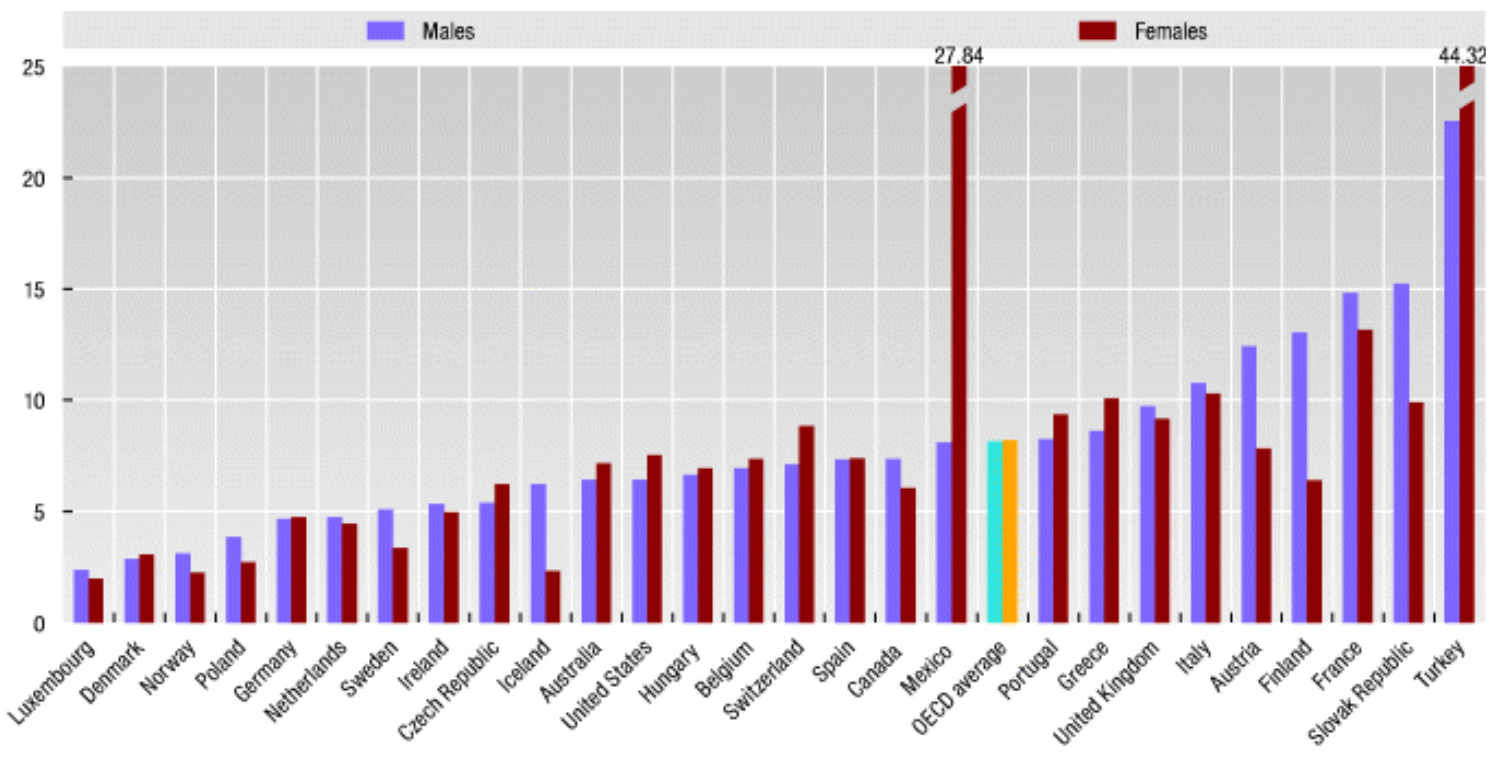

Source: OECD Factbook 2006

The flip side of youth unemployment is the unemployment rate among the elderly. In the age range of 55 and older, unemployment is often disguised as early retirement, often with a disability pension or similar financing mechanisms. Hence, figure 17 depicts the employment rate of individuals aged 55-64.

Sweden has, by far, the highest labor force participation rate in this age range, exceeding that of the United States and even Japan. Denmark and the United Kingdom are also considerably above the EU15 average. 
In turn, France, Italy, Belgium, and Austria have very low labor force participation rates, more than 10 percentage points below the EU15 average and 20 percentage points below the so-called Lisbon Target of 50 percent participation.

Figure 17: Employment Rate of Individuals Aged 55-64, 1992-2004

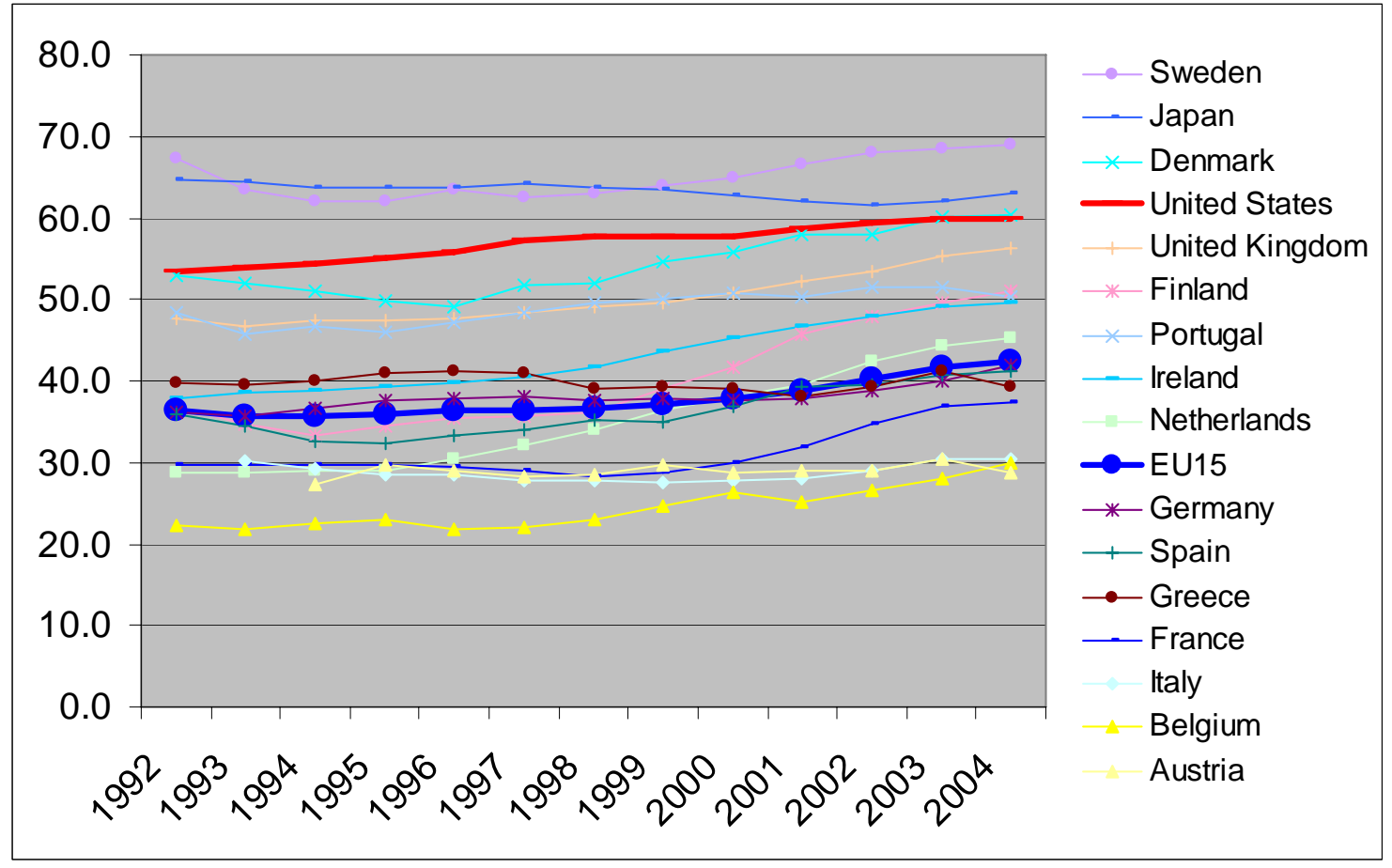

Source: Eurostat Online Data Archive April 2006

\section{3d. Health and Longevity}

Arguably, one of the most important social policy outcomes is health since it is a main driver for well-being. Differences in the health status of a population are very difficult to measure. The SHARE data has a wide array of physical and mental health measures, some selfreported, others physically measured. Two examples of a physical measurement are grip strength and walking speed. They show a remarkably consistent North-South gradient through Europe. 
Figure 18: Walking Speed and Grip Strength of Individuals Aged 50 and Older
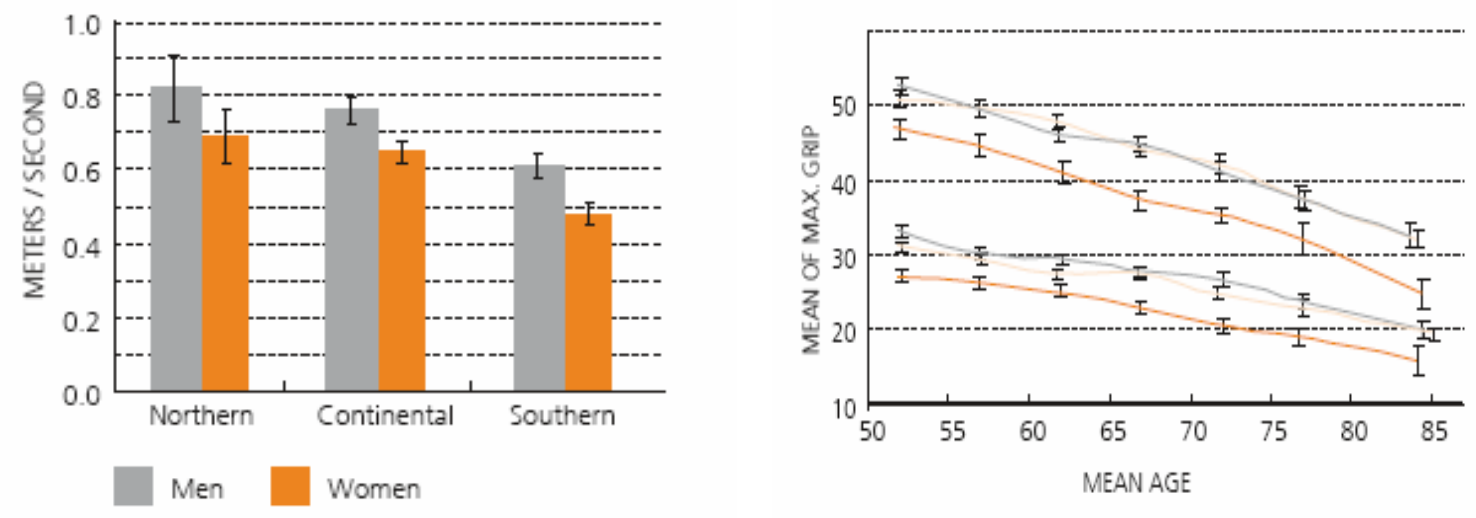

Continental

Southern

Northern

Source: Mackenbach, Avendano, Andersen-Ranberg, and Aro (2005), based on SHARE 2004

Using all available health data in SHARE, including several mental health and cognition tests, Jürges (2005) has developed a comprehensive health index depicted in figure 19.

Figure 19: Comprehensive Health Index of Individuals Aged 50 and Older

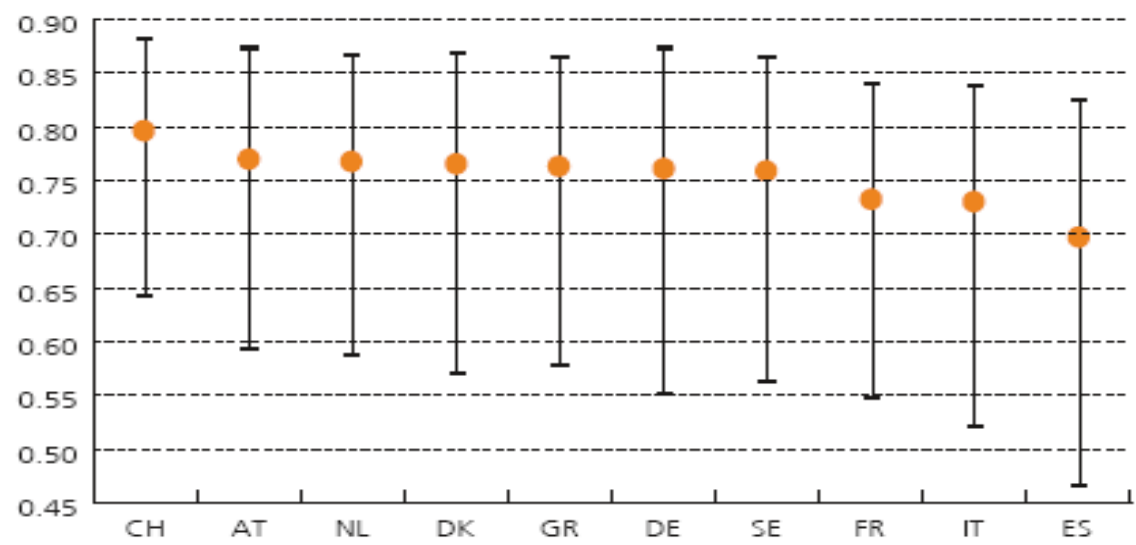

Source: Jürges (2005), based on SHARE 2004

It paints a more detailed picture and identifies Switzerland and Spain as well-defined extremes with a health index well above and well below the SHARE countries' average. Variation in the population is, of course, very large, as shown by the brackets.

Worse health does not necessarily translate in lower life expectancy, as figure 20 shows. Denmark, with one of the highest health indexes has the lowest life expectancy among 
the EU15 countries, and Spain, performing badly on the health index depicted in figure 19, has the highest life expectancy, surpassed only by Japan. This paradox is subject of intensive ongoing research; it is mirrored in the fact that women live longer, but have worse health (for example, see figure 18).

Figure 20

\begin{tabular}{lr}
\hline \multicolumn{2}{c}{$\begin{array}{c}\text { Life expectancy at } \\
\text { birth, 2003 }\end{array}$} \\
\hline Denmark & 77.2 \\
United States & 77.2 \\
Portugal & 77.3 \\
Ireland & 77.8 \\
Belgium & 78.1 \\
Greece & 78.1 \\
Germany & 78.4 \\
Finland & 78.5 \\
United Kingdom & 78.5 \\
Austria & 78.6 \\
Netherlands & 78.6 \\
France & 79.4 \\
Italy & 79.9 \\
Sweden & 80.2 \\
Switzerland & 80.4 \\
Spain & 80.5 \\
Japan & 81.8 \\
\hline
\end{tabular}

Source: OECD Health Data 2005

\section{CAUSES: WHY DID THE EUROPEAN WELFARE STATES BECOME WHAT THEY ARE?}

In the sequel to this paper, we move a few steps toward explaining the magnitude of social expenditures toward the elderly. This is, of course, an undertaking far beyond the scope of a single paper. We begin with demographic and political economy reasons, and then collect some evidence for incentive effects that create an expanded demand for social expenditures toward the elderly, particularly early retirement and disability pensions. 


\section{4a. Demography}

One obvious explanation for the difference in the size of the welfare state and its generosity toward the elderly is, almost a banality, their number. While all European countries are ageing more so than the United States, and all EU15 countries except Ireland have a higher share of older individuals than the United States, Europe is far from homogenous in its current population age structure, as figure 21 shows.

\section{Figure 21: Age Structure of European Countries}
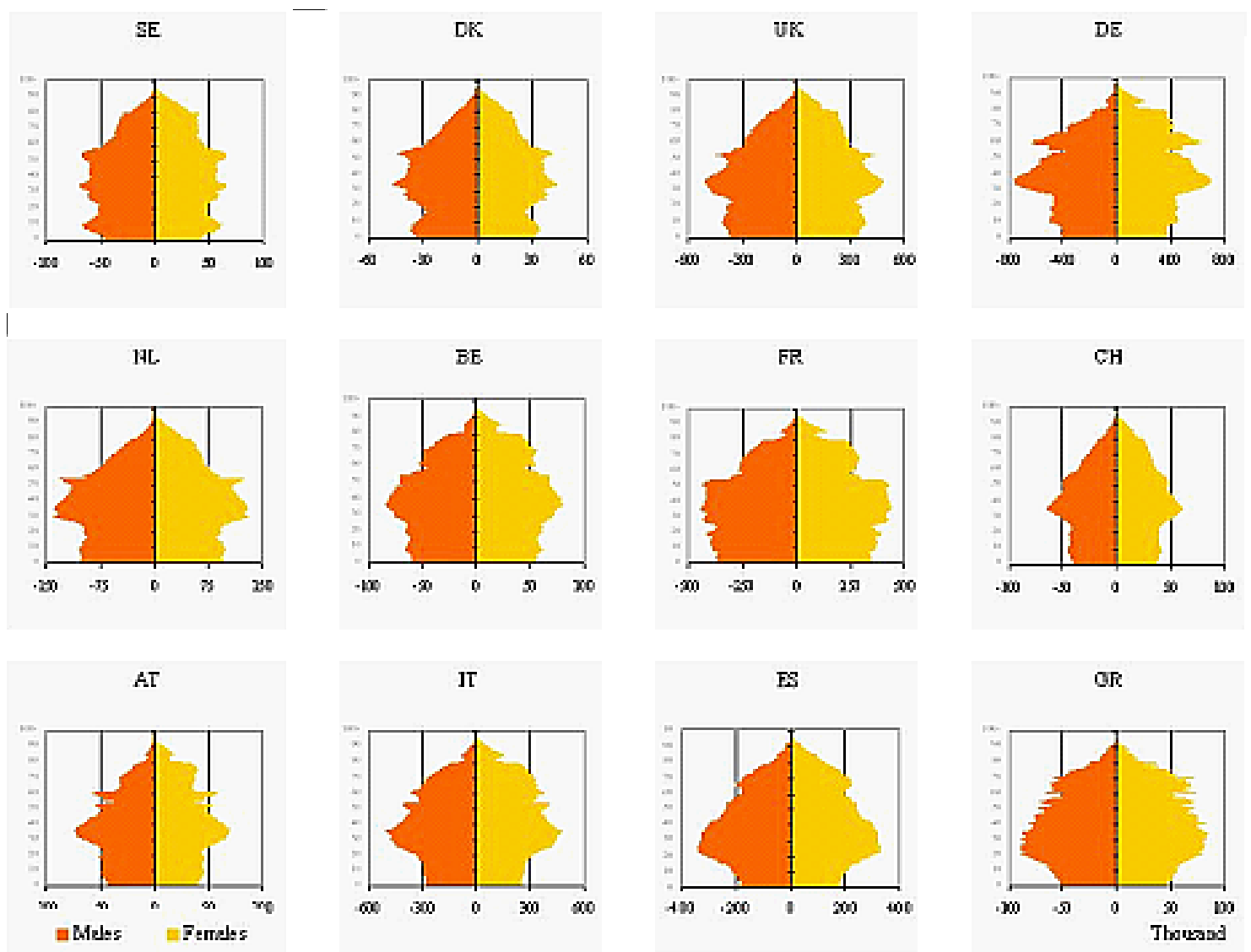

Source: Eurostat 2003

Italy has, by far, the largest share of elderly in the population, explaining part of the huge ratio between spending for the elderly and spending for the young, visible in figure 10.

To proceed somewhat more formally, figure 22 shows time-series, cross-section regressions on the expenditure data depicted in figure 12. The first four regressions are simple pooled OLS regressions. The last two regressions are fixed effects regressions, the first using 
only the cross-national variation, the second only the time-series variation. Indeed, the share of individuals age 65 and older is the key explanatory variable for the spending share on the elderly relative to GDP in almost all regression variants, the only exception being the last regression, indicating that the time-series variation of the elderly share is still very small-the aging process during the 1990-2003 time period is still very modest. As a side product, these regressions also reiterate the positive coefficient of spending for the young, rejecting the crowding-out hypothesis.

Figure 22: Pooled Time-series Cross-section Regressions of Social Expenditures for the Elderly as Percent of GDP

\begin{tabular}{|c|c|c|c|c|c|c|c|c|c|c|c|c|}
\hline oldgdp & Coef. & t-stat & Coef. & t-stat & Coef. & t-stat & Coef. & t-stat & Coef. & t-stat & Coef. & $t$-stat \\
\hline younggdp & 0.252 & 2.6 & 0.197 & 2.0 & 0.263 & 3.6 & 0.129 & 1.9 & 0.057 & 0.8 & 0.733 & 9.8 \\
\hline gdpcap & & & 0.164 & 3.47 & 0.066 & 1.82 & 0.337 & 7.05 & 0.387 & 7.8 & 0.054 & 2.6 \\
\hline $\begin{array}{l}\text { share65p } \\
\text { vear }\end{array}$ & & & & & 1.197 & 12.3 & 1.436 & 15.8 & 1.438 & 15.8 & 0.310 & 4.1 \\
\hline $\begin{array}{l}\text { year } \\
\text { const }\end{array}$ & 12.087 & 23.5 & 9.242 & 9.6 & -7.410 & -4.8 & $\begin{array}{r}-0.416 \\
816.0\end{array}$ & $\begin{array}{r}-7.6 \\
7.6\end{array}$ & -16.181 & -9.4 & 4.062 & 4.3 \\
\hline Adj R-squared & & 0.027 & & 0.080 & & 0.482 & & 0.609 & Within & 0.626 & & 0.485 \\
\hline & & & & & & & & & Between & 0.351 & & 0.150 \\
\hline & & & & & & & & & Overall & 0.404 & & 0.160 \\
\hline
\end{tabular}

Source: Author's regressions based on the data depicted in figure 12.

\section{4b. Political Preferences}

A second potential cause for the spending patterns observed in Section 2 are differences in political preferences. In some countries, a majority of voters may be in favor of more spending on the elderly, in others more on the young. This is, of course, most likely connected to the age structure to of the populace, but there might be additional differences across countries.

Boeri, Börsch-Supan, and Tabellini (2001, 2002, 2004) have conducted a series of small surveys in a few European countries to shed light on the political preferences of European citizens. Their aim was to understand resistance to structural reforms, in particular to pension reforms. A first set of surveys was conducted in Spring 2000 in four countries. The survey was repeated 1.5 years later in Germany and Italy, and once more in Germany in Spring 2003. Figure 23 summarizes results relevant for this paper; the exact wording of the questions are quoted on top of the figure. 
Figure 23: Preferences About Size and Redistribution of Welfare State

(i) Size of welfare state: "Should the state $(+)$ increase pensions and/or transfers, thereby raising taxes and compulsory contributions to households, (0) maintain taxes and compulsory contributions at current levels, or (-) reduce pensions and/or transfers to households, thereby cutting taxes and/or compulsory contributions?"

(ii) Intergenerational redistribution: "Should the state (+) allocate more resources to pensions and less to unemployed or young job seekers, (0) keep the current situation (-), or allocate less resources to pensions and more to unemployed and young job seekers?”

\section{(i) Larger size of welfare state? (ii) More generous to elderly?}

$$
(-)
$$

$(+)$

(0)

$(-)$

\begin{tabular}{lcccccc}
\hline Germany (Spring 2000) & $13 \%$ & $54 \%$ & $25 \%$ & $17 \%$ & $62 \%$ & $22 \%$ \\
Germany (Fall 2001) & $12 \%$ & $48 \%$ & $34 \%$ & $27 \%$ & $51 \%$ & $23 \%$ \\
Germany (Spring 2003) & $19 \%$ & $36 \%$ & $34 \%$ & $19 \%$ & $45 \%$ & $29 \%$ \\
\hline Italy (Spring 2000) & $17 \%$ & $40 \%$ & $43 \%$ & $19 \%$ & $35 \%$ & $46 \%$ \\
Italy (Fall 2001) & $23 \%$ & $47 \%$ & $30 \%$ & $34 \%$ & $28 \%$ & $38 \%$ \\
\hline France (Spring 2000) & $14 \%$ & $51 \%$ & $35 \%$ & $14 \%$ & $66 \%$ & $20 \%$ \\
\hline Spain (Spring 2000) & $31 \%$ & $53 \%$ & $16 \%$ & $10 \%$ & $60 \%$ & $30 \%$ \\
\hline
\end{tabular}

Source: Boeri, Börsch-Supan, and Tabellini (2001, 2002); Börsch-Supan, Heiss, and Winter (2004)

The results show an astounding variation across the four countries. First, the status quo bias is strong in all countries, but weakest in Italy. Second, further expansion of the welfare state does not find majority, but neither its retrenchment. Relatively speaking, the Spanish lean most toward an expansion of the welfare state. Third, except for Germany in 2001 (just after an incisive pension reform), there are more citizens who want to shift the welfare states' generosity from old toward the young than in the reverse order. This is most pronounced in Italy, where this share even surpasses the status quo percentage. Note that this is in stark contrast to the fact that Italy has the oldest populace.

The results in figure 23 align with the actual spending shares (figure 4) and the distribution between old and young (figure 10) in a reverse pattern. Spain has the smallest welfare 
state and wishes to expand most. Italy has the most skewed distribution toward the elderly and wishes to change this most starkly. This may be interpreted as a desire for convergence within Europe, or simply as a tendency to give up easiest those transfers that are supplied most generously, since this is likely to hurt least. Evidence for this interpretation comes from another set of results derived from the 2001 survey by Boeri, Börsch-Supan, and Tabellini (2002). Figure 24 shows how different Germans and Italians judge the attractiveness of six pension reform proposals. Italians would vote in majority for an increase in the retirement age (currently having one of the lowest average exit ages in Europe), while Germans would rather reduce their pension benefits (currently having one of the highest pension benefits, measured in absolute Euro terms at purchasing power).

Figure 24: Preferences About Pension Reform Options

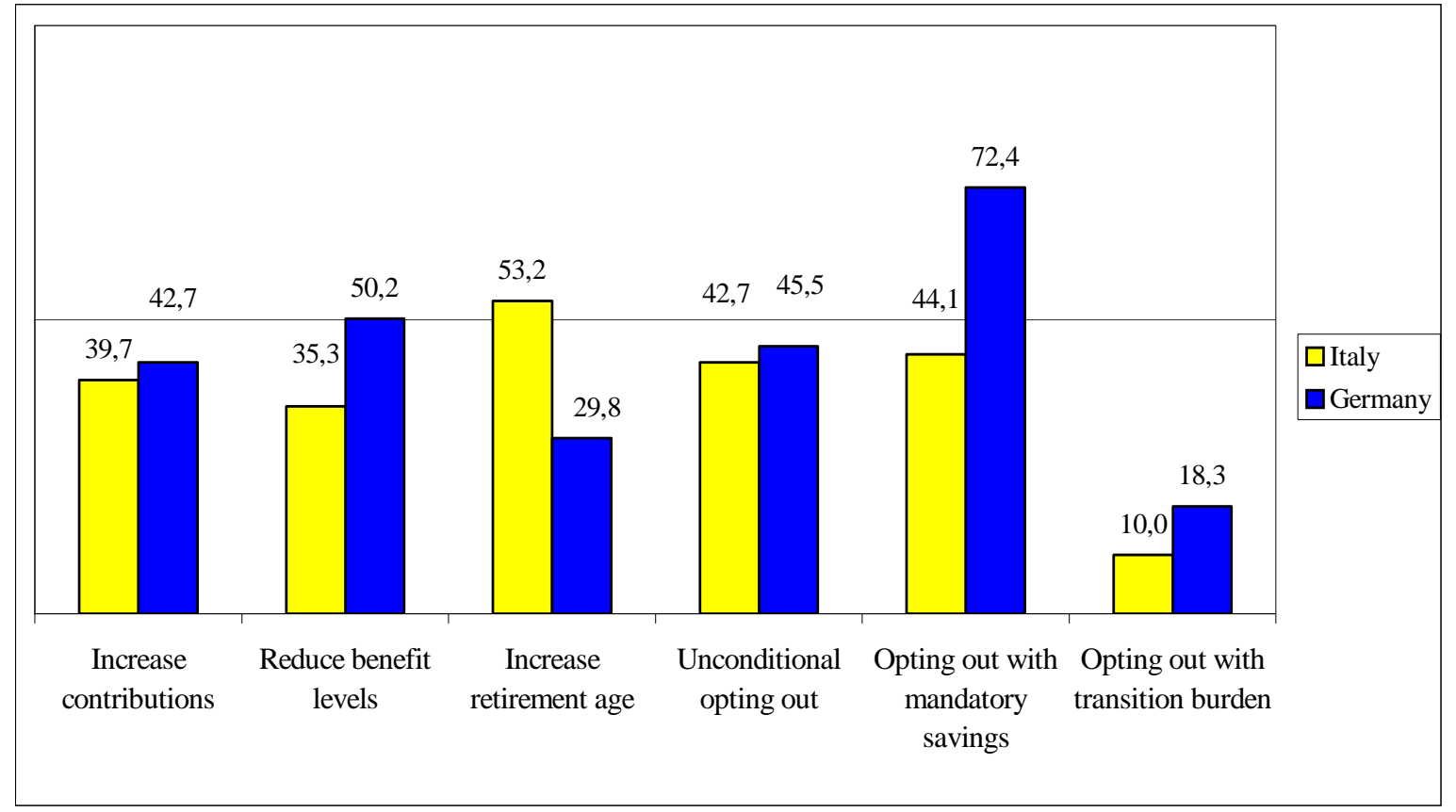

Source: Boeri, Börsch-Supan, and Tabellini (2001, 2002); Börsch-Supan, Heiss, and Winter (2004)

\section{4c. Early Retirement Incentives}

A third reason for the large differences in the size of the welfare state and the generosity toward the elderly are incentive effects in the public transfer systems, especially toward early retirement. Early retirement is widespread in Europe, as the low labor force participation rates among individuals aged 55-64 have indicated in figure 17. Most striking are the crossnational differences in economic activity, vis-à-vis retirement, if differential health (measured 
as a set of functional measures, so-called activities of daily living) is taken account of (see figure 25).

Figure 25: Employment and Retirement Rates Conditional on Good Health
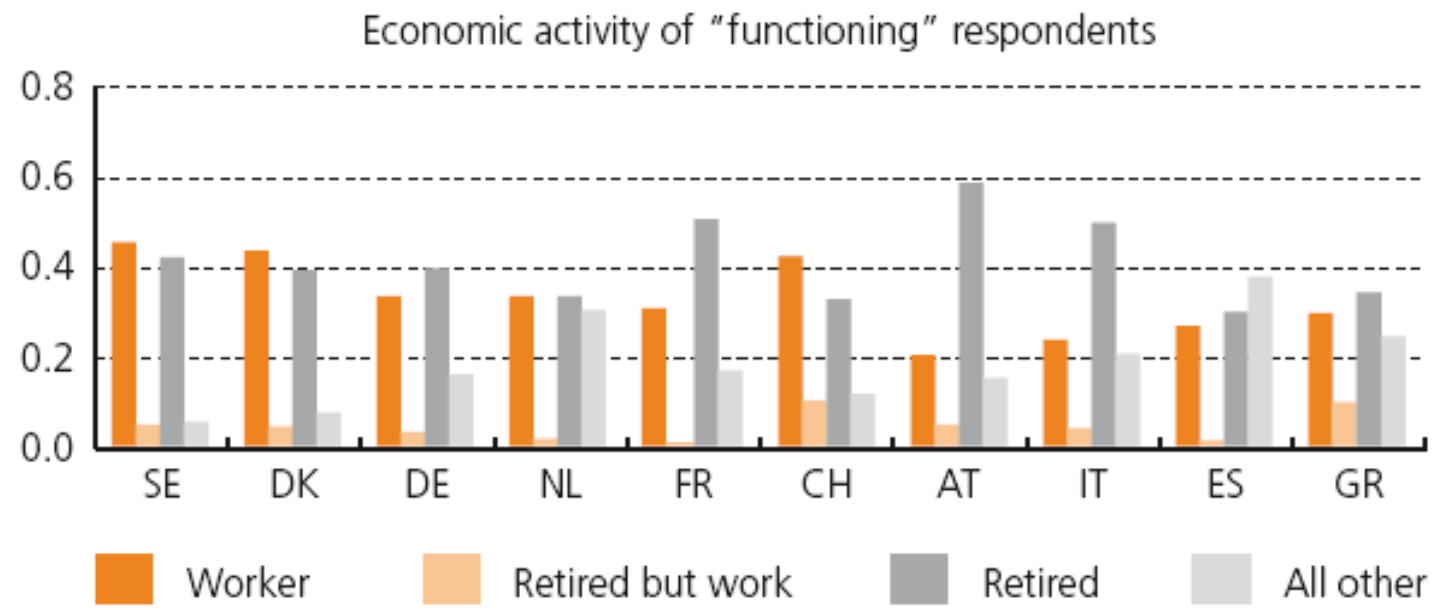

Source: Brugiavini, Croda, and Mariuzzo (2005), based on SHARE 2004.

The cross-national differences are most evident between Sweden and France, for example, or between the Alpine neighbors Austria and Switzerland. To a large extent, these differences can be explained by incentive effects, as the International Social Security Project led by Gruber and Wise has shown. The incentive effects of early old-age pensions measured in this project align very well with the actual early retirement behavior (see figure 26).

Figure 26: Incentive Effects and Retirement Behavior

\begin{tabular}{|c|c|c|c|c|c|c|c|c|}
\hline Country & $\begin{array}{l}\text { Unused } \\
\text { Labor } \\
\text { Capacity, } \\
55-65\end{array}$ & $\begin{array}{l}\text { Men Out } \\
\text { of Labor } \\
\text { Force, } \\
\text { Age } 59\end{array}$ & $\begin{array}{c}\text { Early } \\
\text { Retirement } \\
\text { Age }\end{array}$ & $\begin{array}{c}\text { Replacement } \\
\text { Rate at Early } \\
\text { Retirement } \\
\text { Age (\%) }\end{array}$ & $\begin{array}{c}\text { Accrual in } \\
\text { Next Year } \\
(\%)\end{array}$ & $\begin{array}{c}\text { Implicit Tax } \\
\text { on Earnings } \\
\text { in Next } \\
\text { Year (\%) }\end{array}$ & $\begin{array}{l}\text { Tax Force } \\
\text { Early } \\
\text { Retirement } \\
\text { Age to } 69\end{array}$ & $\begin{array}{l}\text { Hazard Rate } \\
\text { at Early } \\
\text { Retirement } \\
\text { Age (\%) }\end{array}$ \\
\hline Belgium & 67 & 58 & "60" & 77 & -5.6 & 82 & 8.87 & 33 \\
\hline France & 60 & 53 & 60 & 91 & -7.0 & 80 & 7.25 & 65 \\
\hline Italy & 59 & 53 & "55" & 75 & -5.8 & 81 & 9.20 & 10 \\
\hline The Netherlands & 58 & 47 & "60" & 91 & -12.8 & 141 & 8.32 & 70 \\
\hline The United Kingdom & 55 & 38 & 60 & 48 & -10.0 & 75 & 3.77 & 22 \\
\hline Germany & 48 & 34 & 60 & 62 & -4.1 & 35 & 3.45 & 55 \\
\hline Spain & 47 & 36 & 60 & 63 & 4.2 & -23 & 2.49 & 20 \\
\hline Canada & 45 & 37 & 60 & 20 & -1.0 & 8 & 2.37 & 32 \\
\hline The United States & 37 & 26 & 62 & 41 & 0.2 & -1 & 1.57 & 25 \\
\hline Sweden & 35 & 26 & 60 & 54 & -4.1 & 28 & 2.18 & 5 \\
\hline Japan & 22 & 13 & 60 & 54 & -3.9 & 47 & 1.65 & 12 \\
\hline
\end{tabular}

Source: Gruber and Wise (1999) 
Early retirement financed by old-age pensions is only part of the incentive story in Europe. In addition, disability pensions are often a substitute for stricter old-age pensions, often paid without a medical test. Figure 27 shows the large cross-national variation in disability insurance prevalence, both with and without a correction for health. As it turns out, differential health cannot explain the cross-national differences. If they are regressed on variables that measure the generosity of disability pensions, together with the ease of obtaining such a pension, almost 75 percent of the cross-national variation can be explained: 22 percent by the extent of coverage, 14 and 11 percent by the minimum and maximum benefit level, 12 percent by the benefit level at full disability, and 15 percent by the stringency of a medical exam (Börsch-Supan 2006).

Combining the results of figures 26 and 27 helps to explain the large social expenditures to the elderly in Sweden, Denmark, and the Netherlands. While the public pension sector is relatively small in the Netherlands, early retirement is very frequent, and disability uptake as well. Sweden has very generous pensions (that is, for the current elderly under the old pay-as-you-go system) and a generous disability insurance. Denmark spends a lot on a base pension that is generous to the poor and the middle-class, plus a lot on a lenient disability insurance.

Figure 27: Disability Insurance Prevalence, by Correction for Health Status

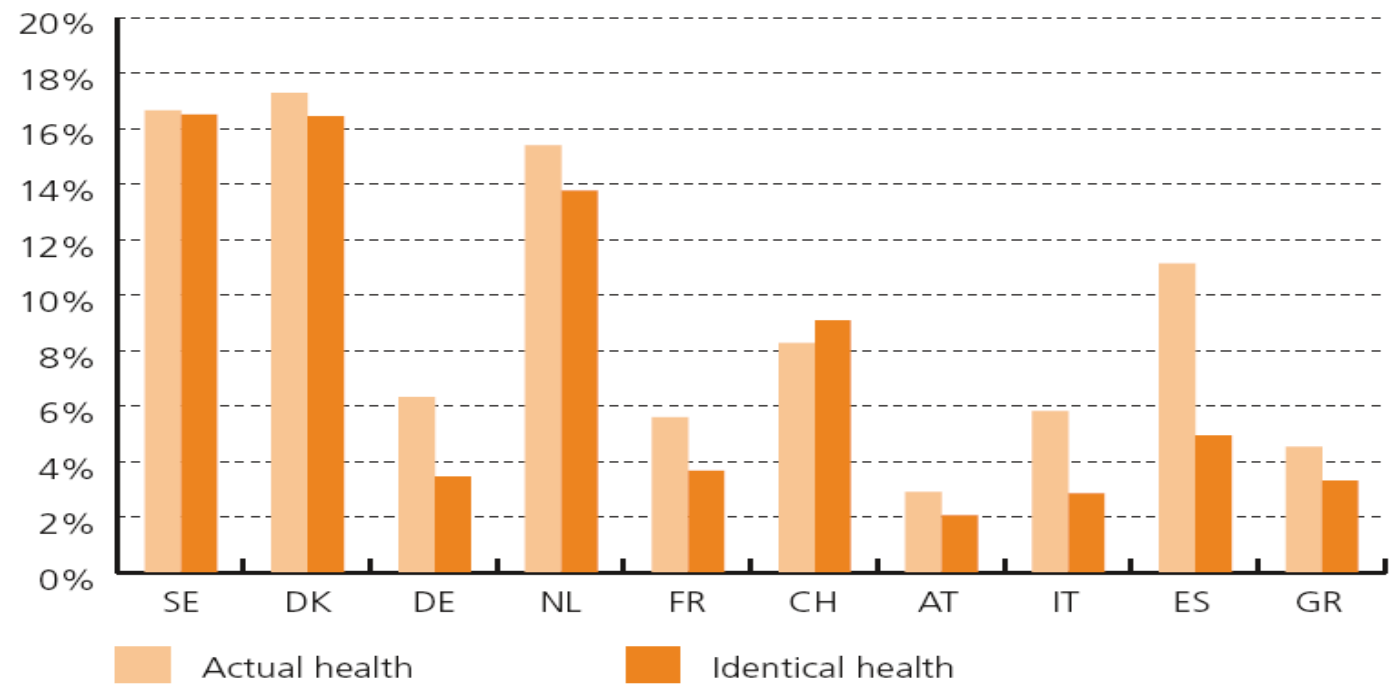

Source: Börsch-Supan (2005), based on SHARE 2004. 


\section{SUMMARY AND CONCLUSIONS}

The aim of this paper was to examine the generosity of the European welfare states toward the elderly. We have used a mixture of aggregate data from EUROSTAT, the OECD, and survey data, in particular from the new Survey of Health, Ageing, and Retirement in Europe (SHARE).

As a first insight from this analysis, we observe that the size of the welfare state varies a great deal in Europe, as well as its relative generosity to the elderly and the young. There is no such thing as "the European welfare state model,” and even the three or four archetypical welfare state models, à la Esping-Andersen (1990, 1999, 2003), mask some highly relevant differences within this typology.

Second, while the size of the welfare states has changed over time-some retrenchment in the early 1990s when measured as share of GDP, but a fairly linear increase in absolute per capita expenditures - the spending patterns and the relative generosity between old and young has remained remarkably stable between 1990 and 2003. There is very little indication of a convergence in spite of the accelerated European integration through the Maastricht process and the introduction of a single currency.

Third, we did not find any convincing evidence for the hypothesis that spending for the elderly crowds out spending for the young. Rather, spending for both age groups has expanded and contracted during the 1990-2003 period with the general size of the welfare state. This does not imply, however, that crowding out might occur at higher spending levels on the elderly in the future when dependency ratios are substantially higher than in the 1990-2003 period.

Fourth, while a causal analysis explaining the size of the various European welfare state models is of course an undertaking far beyond the scope of this single paper, we have identified three dimensions that explain a great deal of the time-series and cross-national variation in welfare state generosity - both in general and as it relates to the elderly. These are the demographic forces of population aging which differ widely across European countries; political preferences pushing politicians in directions different across Europe; and incentive effects that create an expanded demand for social expenditures toward the elderly (in particu- 
larly early retirement and disability benefits) that are more pronounced in some European countries than in others.

These incentive effects are the key mechanisms by which government spending is crowding out economic activity. In the light of the accelerating demographic change during the coming decades, they need to be taken seriously because the trade-off between welfare state generosity and economic activity, by which this paper started, is getting harsher as aging progresses. Policies which maintain spending levels but minimize incentive effects are particularly attractive. Examples are flexible retirement rules with actuarial benefit rules that strengthen labor supply and public defined benefit plans indexed to demography that strengthen private old-age provision. 


\section{REFERENCES}

Aarts, L.J.M., R.V. Burkhauser, and P.R. de Jong (eds). 1996. Curing the Dutch disease. An international perspective on disability policy reform. Aldershot: Avebury.

Attias-Donfut, C. (ed.) 1995. Les solidarités entre générations: Vieillesse, familles, État. Paris, Nathan, collection Essais et Recherche, Série Sciences Sociales.

Becker, U. 2000. "Welfare state development and employment in the Netherlands in comparative perspective.” Journal of European Social Policy 10: 219-239.

Berkel, B. and A. Börsch-Supan. 2003. "Pension Reform in Germany: The Impact on Retirement Decisions.” Finanzarchiv 60(3): 393-421.

Boeri, T., A. Börsch-Supan, and G. Tabellini. 2004. "How would you like to reform your pension system? The opinions of German and Italian citizens.” In R. Brooks and A. Razin (eds.) Politics and Finance of Social Security Reform. Cambridge: Cambridge University Press.

2002. "Would you like to Reform the Pension System? The Opinions of European Citizens.” American Economic Review 92: 396-401.

2001. "Would you like to Shrink the Welfare State? The Opinions of European Citizens.” Economic Policy 32: 7-50.

Bonsang, E., S. Perelman, and K. van den Bosch. 2005. "Income, Wealth and Consumption Inequality.” In Börsch-Supan et al. (eds.) Health, ageing and retirement in Europe First results from the Survey of Health, Ageing and Retirement in Europe. Mannheim, Germany: MEA.

Börsch-Supan, A. 2006. "Work Disability, Health and Incentive Effects” (forthcoming) In D. Wise New Themes in the Economics of Aging. Chicago: University of Chicago Press.

2000. "Incentive Effects of Social Security on Labor Force Participation: Evidence in Germany and across Europe.” Journal of Public Economics 78: 25-49.

Börsch-Supan, A., A. Brugiavini , H. Jürges, J. Mackenbach, J. Siegrist, and G. Weber (eds). 2005. Health, ageing and retirement in Europe - First results from the Survey of Health, Ageing and Retirement in Europe. Mannheim, Germany: Mannheim Research Institute for the Economics of Aging. 
Börsch-Supan, A. and J. Jürges (eds.). 2005. The Survey of Health, Ageing and Retirement in Europe - Methodology. Mannheim, Germany: Mannheim Research Institute for the Economics of Ageing (forthcoming).

Börsch-Supan, A. and R. Schnabel. 1998. "Social Security and Declining Labor-Force Participation in Germany.” American Economic Review 88: 173-178.

Brugiavini, A., E. Croda, and F. Mariuzzo. 2005. "Labour Force Participation of the Elderly: Unused Capacity?” In Börsch-Supan et al. (eds) Health, ageing and retirement in Europe - First results from the Survey of Health, Ageing and Retirement in Europe. Mannheim, Germany: MEA

Casey, B.H. 2004. "The OECD Jobs Strategy and the European Employment Strategy: Two Views of the Labour Market and the Welfare State.” European Journal of Industrial Relations 10: 329-352.

Choi, N.G. 2000. "Determinants of engagement in paid work following social security benefit receipt among older women.” Journal of Women and Aging 12(3-4): 133-54.

Cigno, Alessandro. 1996. "Jointly determined saving and fertility behaviour: Theory, and estimates from Germany, Italy, UK, and USA” (with F.C. Rosati). European Economic Review 40: 1561-1589.

Daatland, S. O. and K. Herlofson. 2003. "Lost Solidarity or Changed Solidarity: A comparative European view of normative family solidarity.” Ageing and Society 235: 537-560.

Dahl E., J. Fritzell, E. Lahelma, P. Martikainen, A. Kunst, and J. Mackenbach. 2005. "Welfare state regimes and health inequalities.” In J. Siegrist and M. Marmot (eds.) Social Inequalities in Health: New Evidence and Policy Implications. Oxford: Oxford University Press (in press).

Dewey, M.E. and M. J. Prince. 2005. “Mental health.” In Börsch-Supan, A., et al. (eds.) Health, ageing and retirement in Europe - First results from the Survey of Health, Ageing and Retirement in Europe. 108-117. Mannheim, Germany: Mannheim Research Institute for the Economics of Aging.

Esping-Andersen, G. 1990. The Three Worlds of Welfare Capitalism. Princeton.

1999. Social Foundations of Postindustrial Economies. Oxford.

2003. A welfare state for the 21st century. In A. Giddens (ed.) The Global Third Way Debate. 134-56. Oxford: Polity Press. 
Gornick, J.C. and J.A. Jacobs. 1998. "Gender, the welfare state, and public employment: A comparative study of seven industrialized countries.” American Sociological Review 63: 688-710.

Gruber, J. and D. Wise (Hrsg.). 1999. Social Security and Retirement Around the World. Chicago: University of Chicago Press.

Hayward, M. D. and Z. Zhang. 2001. “Demography of aging.” In Binstock, R.H. and George L.K. (eds.) Handbook of aging and the social sciences ( $5^{\text {th }}$ ed.). 69-85. San Diego: Academic Press.

Hurd, M. and A. Kapteyn. 2003. "Health, wealth, and the role of institutions.” Journal of Human Resources 38: 386-415.

Jürges, H. 2005. “Cross-Country Differences in General Health.” In Börsch-Supan, A. et al. (eds.) Health, ageing and retirement in Europe - First results from the Survey of Health, Ageing and Retirement in Europe. Mannheim, Germany: MEA.

Kohli, M., M. Rein, A.M. Guillemard, and H. van Gunsteren (eds.). 1991. Time for retirement: Comparative studies of early exit from the labor force. Cambridge: Cambridge University Press.

Künemund, H. and M. Rein. 1999. „There is More to Receiving Than Needing: Theoretical Arguments and Empirical Explorations of Crowding In and Crowding Out.” Ageing and Society 19: 93-121.

Lyberaki, A., and P. Tinios. 2005. "Poverty and Social Exclusion: A New Approach to an Old Issue.” In Börsch-Supan, A. et al. (eds.) Health, ageing and retirement in EuropeFirst results from the Survey of Health, Ageing and Retirement in Europe. Mannheim, Germany: MEA.

Mackenbach, J., M. Avendano, K. Andersen-Ranberg, and A.R. Aro. 2005. "Socio-Economic sparities in Physical Health in 10 European Countries.” In Börsch-Supan, A. et al. (eds.) Health, ageing and retirement in Europe - First results from the Survey of Health, Ageing and Retirement in Europe. Mannheim, Germany: MEA.

OECD. 2006. OECD Factbook. Paris: OECD. Available online at: http://caliban.sourceoecd.org/vl=3040935/cl=12/nw=1/rpsv/factbook/

WHO. 2002. Active ageing: A policy framework. World Health Organization, Geneva. 
Wilke, C.B. 2006. "Income levels of individuals aged 50 and older: Effective and comprehensive replacement rates based on the SHARE data.” Mimeo. Mannheim, Germany:

Mannheim Research Institute for the Economics of Aging. 